
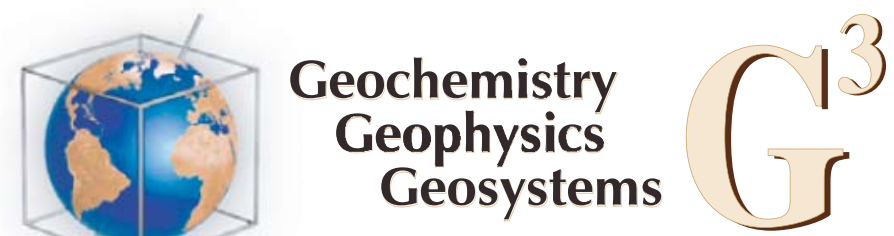

Published by AGU and the Geochemical Society

\title{
Effusive and explosive volcanism on the ultraslow-spreading Gakkel Ridge, $85^{\circ} \mathrm{E}$
}

\author{
Claire W. Pontbriand \\ MIT-WHOI Joint Program in Oceanography, 266 Woods Hole Road, MS 24, Woods Hole, \\ Massachusetts 02543,USA (ccwillis@mit.edu)
}

\section{S. Adam Soule, Robert A. Sohn, Susan E. Humphris, Clayton Kunz, and Hanumant Singh Woods Hole Oceanographic Institution, 266 Woods Hole Road, MS 24, Woods Hole, Massachusetts 02543,USA (ssoule@whoi.edu; rsohn@whoi.edu; shumphris@whoi.edu; ckunz@whoi.edu; bsingh@whoi.edu)}

\section{Ko-ichi Nakamura}

Institute of Geology and Geoinformation, National Institute of Advanced Industrial Science and Technology, 1-1-1 Higashi, Tsukuba 305-8567, Japan (koichi.nakamura@aist.go.jp)

\section{Martin Jakobsson}

Department of Geological Sciences, Stockholm University, SE-10691 Stockholm, Sweden (martin.jakobsson@geo.su.se)

\section{Timothy Shank}

Woods Hole Oceanographic Institution, 266 Woods Hole Road, MS 24, Woods Hole, Massachusetts 02543, USA (tshank@whoi.edu)

[1] We use high-definition seafloor digital imagery and multibeam bathymetric data acquired during the 2007 Arctic Gakkel Vents Expedition (AGAVE) to evaluate the volcanic characteristics of the $85^{\circ} \mathrm{E}$ segment of the ultraslow spreading Gakkel Ridge $\left(9 \mathrm{~mm} \mathrm{yr}^{-1}\right.$ full rate). Our seafloor imagery reveals that the axial valley is covered by numerous, small-volume (order $\sim 1000 \mathrm{~m}^{3}$ ) lava flows displaying a range of ages and morphologies as well as unconsolidated volcaniclastic deposits with thicknesses up to $10 \mathrm{~cm}$. The valley floor contains two prominent volcanic lineaments made up of axis-parallel ridges and small, cratered volcanic cones. The lava flows appear to have erupted from a number of distinct source vents within the $\sim 12-15 \mathrm{~km}$-wide axial valley. Only a few of these flows are fresh enough to have potentially erupted during the 1999 seismic swarm at this site, and these are associated with the Oden and Loke volcanic cones. We model the widespread volcaniclastic deposits we observed on the seafloor as having been generated by the explosive discharge of $\mathrm{CO}_{2}$ that accumulated in (possibly deep) crustal melt reservoirs. The energy released during explosive discharge, combined with the buoyant rise of hot fluid, lofted fragmented clasts of rapidly cooling magma into the water column, and they subsequently settled onto the seafloor as fall deposits surrounding the source vent.

Components: 13,400 words, 10 figures.

Keywords: mid-ocean ridge; seafloor morphology; submarine explosive volcanism; ultraslow spreading.

Index Terms: 3035 Marine Geology and Geophysics: Midocean ridge processes; 3045 Marine Geology and Geophysics: Seafloor morphology, geology, and geophysics; 8428 Volcanology: Explosive volcanism (4302). 
Received 13 April 2012; Revised 21 August 2012; Accepted 23 August 2012; Published 6 October 2012.

Pontbriand, C. W., S. A. Soule, R. A. Sohn, S. E. Humphris, C. Kunz, H. Singh, K. Nakamura, M. Jakobsson, and T. Shank (2012), Effusive and explosive volcanism on the ultraslow-spreading Gakkel Ridge, $85^{\circ}$ E, Geochem. Geophys. Geosyst., 13, Q10005, doi:10.1029/2012GC004187.

\section{Introduction}

[2] Volcanic processes at mid-ocean ridges (MORs) generate the oceanic crust comprising more than $60 \%$ of the Earth's solid surface. Plate spreading rate is perhaps the dominant parameter controlling crustal accretion and volcanic processes at MORs, with faster spreading ridges receiving a higher magma supply rate and exhibiting a hotter thermal structure compared to slower spreading ridges [Macdonald, 1982; Smith and Cann, 1993; Perfit and Chadwick, 1998; Edwards et al., 2001; Sinton et al., 2002; Cann and Smith, 2005; Cochran, 2008; Searle et al., 2010]. Although the first-order effects of spreading rate on ridge morphology (e.g., axial rise versus rift valley) and thermal structure are well-established [Sinton and Detrich, 1992; Smith and Cann, 1993; Small, 1994; Fornari et al., 2004; Cann and Smith, 2005; Rubin and Sinton, 2007; Behn and Ito, 2008; Soule et al., 2009], the implications for volcanic eruption processes (e.g., volume, spatial extent, frequency, effusion rate, and lava composition) are not fully understood. Many seafloor-mapping studies have constrained the nature of volcanic processes across the global MOR system [e.g., Ballard and van Andel, 1977; Bonatti and Harrison, 1988; Perfit and Chadwick, 1998; Sinton et al., 2002; Baker et al., 2004; Soule et al., 2005, 2007], however, volcanic processes at the most slowly diverging plate boundaries are poorly constrained. Limited seafloor-mapping studies have been conducted at ultraslow spreading ridges [e.g., Edwards et al., 2001; Dick et al., 2003; Edwards and Coakley, 2003; Michael et al., 2003; Standish et al., 2008] and even fewer with observations at the scale of individual eruptions owing to the logistical and technical challenges associated with working in the rough seas of the Southern Ocean (i.e., Southwest Indian Ridge) and under the perennial ice pack of the Arctic Ocean (i.e., Gakkel Ridge), where a large fraction of ultraslow-spreading ridges occur.

[3] The Gakkel Ridge exhibits full spreading rates that systematically decrease from $12.8 \mathrm{~mm} \mathrm{yr}^{-1}$ at its western end (near Greenland) to $6.5 \mathrm{~mm} \mathrm{yr}^{-1}$ at its eastern end (the Siberian margin) [Vogt et al.,
1979; DeMets et al., 1994; Sella et al., 2002]. The latter are the slowest MOR spreading rates found on Earth. Melting models of MORs predict a sharp decrease in magma production and crustal thickness when full spreading rates are lower than $\sim 20 \mathrm{~mm} \mathrm{yr}^{-1}$ [Reid and Jackson, 1981; Bown and White, 1994], suggesting that magma supply should be reduced along the entire $1800 \mathrm{~km}$ length of the ridge. Bathymetric surveys and dredging studies conducted during the AMORE expedition [Dick et al., 2003; Michael et al., 2003], along with geophysical surveys [Coakley and Cochran, 1998; Jokat et al., 2003], have demonstrated that the igneous crust does become 'vanishingly thin' in some places, presumably because relatively low and intermittent magma supply rates lead to avolcanic extension and exhumation of ultra-mafic lithologies [Smith and Cann, 1993; Sinton and Detrich, 1992; Cannat, 1996; Dick et al., 2003; Cann and Smith, 2005; Rubin and Sinton, 2007; Behn and Ito, 2008]. However, the ridge exhibits significant along-axis variations in magma supply, and some segments appear to be magmatically robust with crustal thicknesses up to $2 \mathrm{~km}$ greater than at nearby avolcanic segments [Jokat and Schmidt-Aursch, 2007]. These results indicate that the relationship between spreading rate and magma supply is not systematic on the scale of individual ridge segments, and that volcanic processes are highly heterogeneous at ultraslow spreading rates.

[4] Spreading rates along the global MOR system range from ultrafast $\left(>160 \mathrm{~mm} \mathrm{yr}^{-1}\right.$, full rate) to ultraslow $\left(<12 \mathrm{~mm} \mathrm{yr}^{-1}\right)$. Fast spreading ridges are believed to experience frequent (order 10-100 years), small-volume, volcanic eruptions along a narrow, axial neovolcanic zone that reflect a relatively high magma supply rate [e.g., Macdonald, 1982; Perfit and Chadwick, 1998; Sinton et al., 2002; Soule et al., 2007]. Morphologically, fast spreading ridges exhibit an axial high with a narrow, semi-continuous, graben [Small, 1994; Fornari et al., 2004; Soule et al., 2009]. By contrast, at slow-spreading ridges the dominant morphologic feature is a rift valley, which is believed to reflect relatively low and intermittent magma supply rates combined with increased tectonic crustal extension [Smith and Cann, 1993; 
Sinton and Detrich, 1992; Cann and Smith, 2005; Rubin and Sinton, 2007; Behn and Ito, 2008]. Volcanic eruptions at slow spreading ridges are thought to be infrequent (order 1000-10,000 years), and to produce discrete, point-source volcanic constructions across the rift valley floor [Smith and Cann, 1993; Cann and Smith, 2005; Cochran, 2008; Searle et al., 2010].

[5] Given the rift valley morphology and intermittent and likely reduced magma supply for volcanic processes at ultraslow-spreading ridges, magma chambers are thought to lie beneath thicker, stronger, lithospheric lids, and therefore require larger magma pressures to induce eruption. Thus it has been hypothesized that ultraslow spreading ridges experience large $\left(1-10 \mathrm{~km}^{3}\right)$ and infrequent (order $10,000-100,000$ years) volcanic eruptions and, more generally, that eruption volume scales inversely with spreading rate [Perfit and Chadwick, 1998; Sinton et al., 2002]. Recently the deep-submergence technology to allow for direct visual observations of the Gakkel Ridge and detailed mapping of lava flows beneath the perennial pack ice has made it possible to test these hypotheses. In 2007 the AGAVE expedition utilized a novel vehicle (CAMPER) to acquire high-definition digital imagery and precisely located rock samples from the Gakkel Ridge at the $7^{\circ} \mathrm{E}$ and $85^{\circ} \mathrm{E}$ sites beneath the pack ice. Initial results from the $85^{\circ} \mathrm{E}$ site demonstrated that large portions of the seafloor in this area are blanketed with pyroclastic material from explosive eruptions [Sohn et al., 2008]. We expand on this result by using the complete suite of dive images to constrain volcanic processes at the scale of individual lava flows. Our dive imagery demonstrates that the seafloor in this area is covered by a large number of small lava flows, as opposed to a single, large-volume flow, which is at odds the hypothesis that eruption volume varies inversely with spreading rate [Perfit and Chadwick, 1998; Sinton et al., 2002]. We use our dive images to develop a new model for volcanic processes at the $85^{\circ} \mathrm{E}$ segment, and discuss the implications of this model for ultraslow-spreading volcanic processes, in general.

\section{Gakkel Ridge and the $85^{\circ} \mathrm{E}$ Site}

[6] Dredging studies along the Gakkel Ridge have recovered a mix of ultramafic and mafic lithologies reflecting spatial and temporal variations in magma supply [Dick et al., 2003; Michael et al., 2003]. Dredging from the AMORE expedition in 2001 led to the division of the Gakkel Ridge into three distinct tectono-magmatic provinces: the Western Volcanic Zone (WVZ) from $7^{\circ} \mathrm{W}$ to $3^{\circ} \mathrm{E}$, the Sparsely Magmatic Zone (SMZ) from $3^{\circ}$ to $29^{\circ} \mathrm{E}$, and the Eastern Volcanic Zone (EVZ) from $29^{\circ}$ to $96^{\circ} \mathrm{E}$ [Michael et al., 2003] (Figure 1a). The AMORE expedition dredged almost exclusively basalt lithologies from within the axial valley of the Western Volcanic Zone, and aeromagnetic studies revealed a continuous magnetic anomaly along the rift valley [Jokat and Schmidt-Aursch, 2007], consistent with sustained volcanic accretion for the past at least 25 Myr [Jokat et al., 2003]. By contrast, dredges acquired from the Sparsely Magmatic Zone contained a mixture of basalt and peridotite lithologies, indicating that in some places the magma supply is insufficient to sustain volcanic accretion, leading to the exhumation of peridotite lithologies by extensional faulting. This hypothesis is consistent with large free-water gravity anomalies $(85-150 \mathrm{mGal})$ observed over the ridge axis in this zone [Coakley and Cochran, 1998]. Along the Eastern Volcanic Zone the ridge appears to consist of at least seven widely spaced $(\sim 30 \mathrm{~km})$ volcanic centers. The average depth of the axial valley of the Gakkel Ridge $(4600 \mathrm{~m}$ to $5100 \mathrm{~m})$ is deeper than those of the Mid-Atlantic Ridge (3500-4000 m) and South West Indian Ridge (3090-4730 m) (Figure 2) [Le Douaran and Francheteau, 1981; Sempéré et al., 1990, 1993; Neumann and Forsyth, 1993; Cannat et al., 1999]. At the easternmost end of the ridge the axial valley becomes buried in sediments from the Siberian margin, and gravity data suggest the crust becomes 'vanishingly' thin [Coakley and Cochran, 1998].

[7] The $85^{\circ} \mathrm{E}$ segment of the Gakkel Ridge is of particular interest because in 1999 it hosted the largest earthquake swarm detected to-date by the Global Seismic Network on the spreading axis of a MOR [Müller and Jokat, 2000; Tolstoy et al., 2001]. Two hundred and fifty two earthquakes with magnitudes ranging from 3.2 to 5.8 were detected during a seven-month swarm, and many events during the first few months exhibited non-double couple focal mechanism solutions, which are believed to indicate volcanic activity [Müller and Jokat, 2000; Tolstoy et al., 2001; Korger and Schlindwein, 2012]. Geophysical surveys of the $85^{\circ} \mathrm{E}$ segment from a nuclear submarine (SCICEX expedition) following the onset of the swarm (summer of 1999) imaged a large region of high acoustic backscatter covering the entire axial valley (Figure 3), which was interpreted to represent multiple unsedimented, voluminous lava flows [Edwards et al., 2001]. The AMORE 
A.

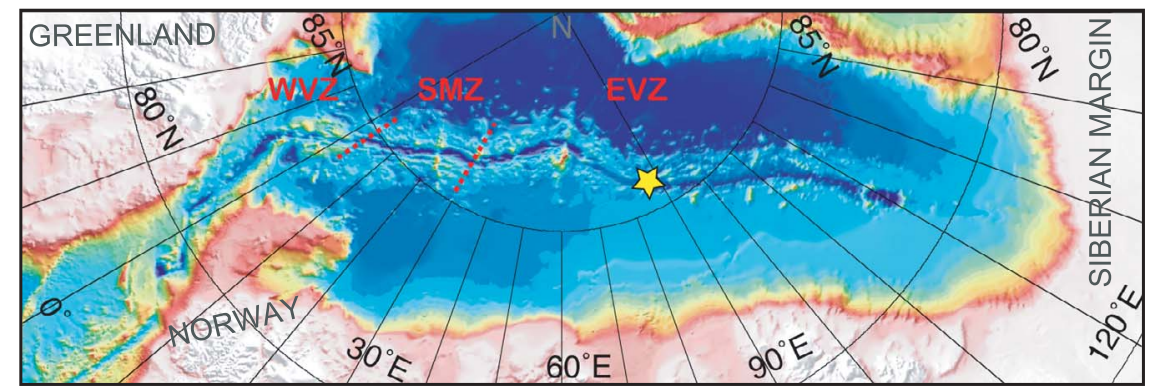

B.

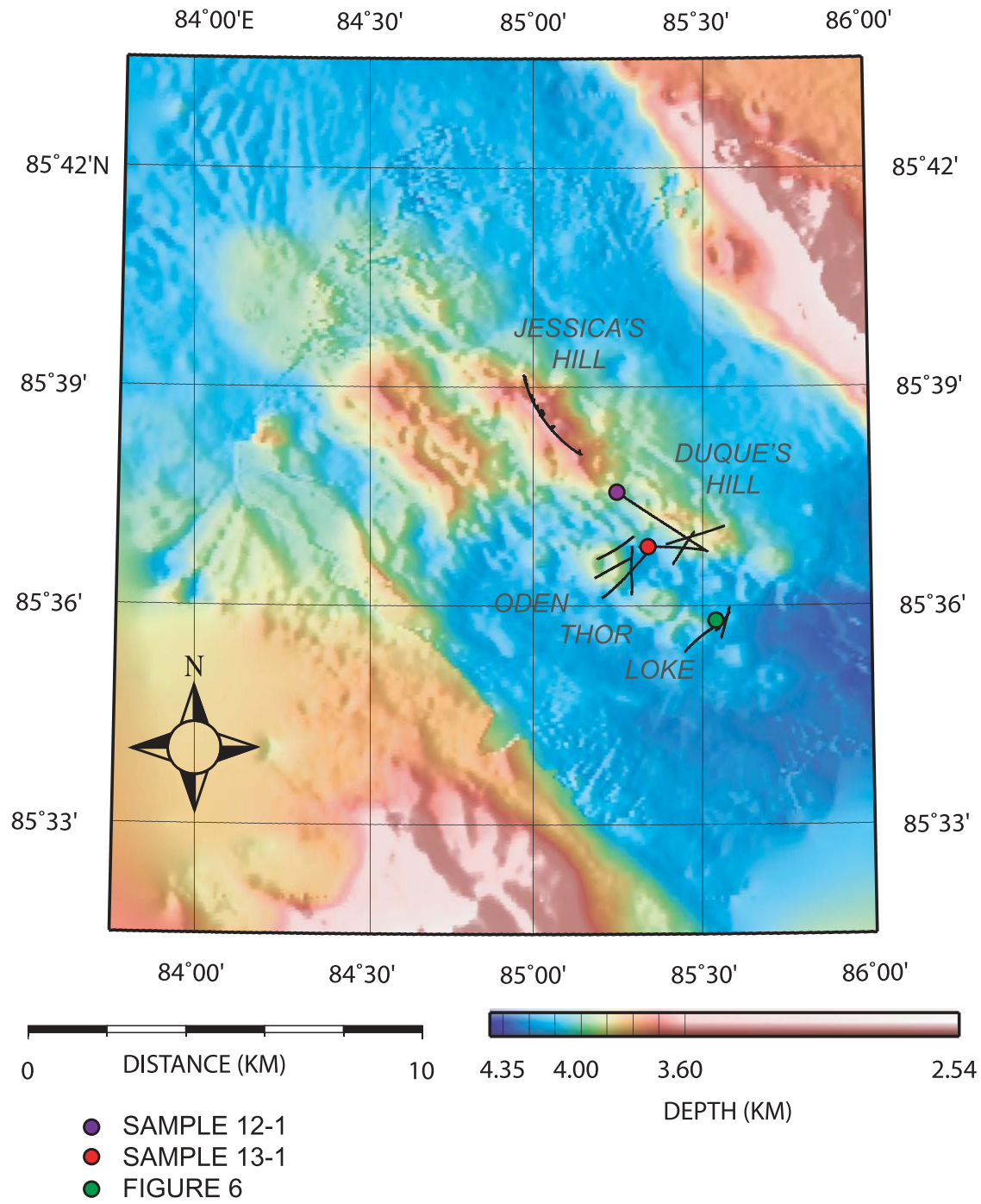

Figure 1. Study Area at $85^{\circ}$ E, Gakkel Ridge. (a) The Gakkel Ridge extends $1800 \mathrm{~km}$ across the Arctic Basin. A star denotes our study area within the Eastern Volcanic Zone (EVZ). (b) A bathymetric chart of the axial valley of the Gakkel Ridge at $85^{\circ} \mathrm{E}$. Depths range from $2543 \mathrm{~m}$ at the rift valley walls to $4351 \mathrm{~m}$ on the axial valley floor. Axial ridges and volcanic cones lie on two axis-parallel lineations of focused volcanism in the center of the rift valley. Black tracks denote the paths of near-seafloor CAMPER vehicle deployments. Circles denote the locations of samples of volcaniclastic deposits and the Figure 6 mosaic.

expedition, which returned to the $85^{\circ} \mathrm{E}$ site in 2001 , found evidence for a hydrothermal 'megaplume' in the water column over the axial valley [Edmonds et al., 2003] and seismometers deployed on ice floes over the site recorded explosive reports interpreted to represent ongoing volcanic activity [Schlindwein et al., 2007; Schlindwein and Riedel, 2010]. All of this evidence led to the hypothesis that the $85^{\circ} \mathrm{E}$ 


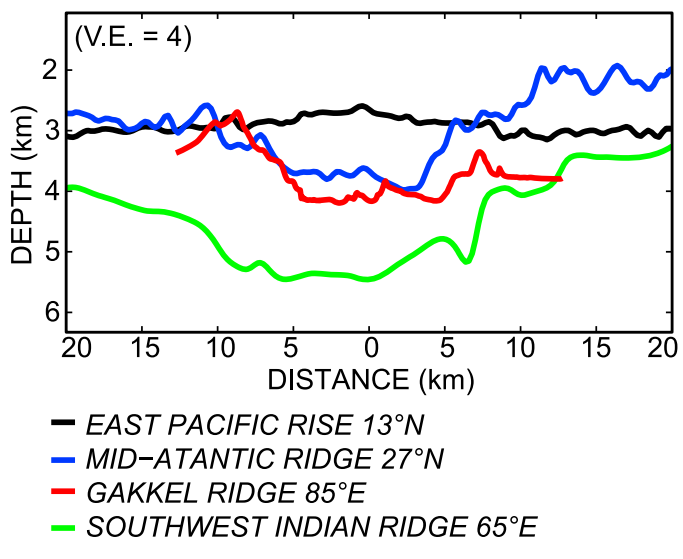

Figure 2. Profiles of the fast spreading (East Pacific Rise), slow spreading (Mid-Atlantic Ridge), and ultraslowspreading ridges (Southwest Indian Ridge, Gakkel Ridge) show how axial morphology and depth vary with spreading rate.

segment has been undergoing a phase of active volcanism wherein it has produced frequent and voluminous lava flows and vigorous, sustained, hydrothermal discharge [Müller and Jokat, 2000; Edwards et al., 2001; Tolstoy et al., 2001; Edmonds et al., 2003; Baker et al., 2004].

[8] The AGAVE expedition returned to the $85^{\circ} \mathrm{E}$ site in 2007 with a towed camera and sampling system (CAMPER) capable of returning highdefinition video and still imagery of the seafloor beneath the ice cap. This imagery revealed that major portions of the axial valley are blanketed with volcaniclastic deposits interpreted to result from magma fragmentation during explosive eruptions [Sohn et al., 2008]. The fragmentation mechanism for the volcaniclasts is enigmatic because: (a) mid-ocean ridge basalts typically exhibit volatile contents well below what is necessary for magmatic fragmentation [Wright, 1994; Clague et al., 2000; Head and Wilson, 2003], (b) hydrostatic pressures on the axial valley floor at an average depth of $3870 \mathrm{~m}$ are well above the critical point for steam formation, which appears to rule out hydrovolcanic fragmentation (i.e., interaction with seawater) [Driesner and Geiger, 2007], and (c) fragmentation due to cooling (quench granulation) is inconsistent with the seafloor distribution and morphology of the clasts. These considerations led Sohn et al. [2008] to propose that the volcaniclastic material was fragmented by magmatic volatiles (e.g., $\mathrm{CO}_{2}$ ) sequestered in large crustal melt bodies. Melt inclusions trapped in volcaniclastic glasses recorded high $\mathrm{CO}_{2}$ concentrations (167-1596 ppm) consistent with entrapment of
$\mathrm{CO}_{2}$ saturated magma at depths $>9 \mathrm{~km}$ in the crust [Shaw et al., 2010]. Similar interpretations have also been suggested for volcaniclastic deposits at other deep oceanic spreading centers [Clague et al., 2003, 2009] and these are among a growing number of observations attributing fragmentation to magmatic volatiles in submarine volcanic systems [Wright, 1994; Clague et al., 2000, 2003, 2009; Chadwick et al., 2008; Schipper and White, 2010; Deardorff et al., 2011; Helo, et al., 2011; Resing et al., 2011].

\section{Data and Methods}

\subsection{Bathymetry}

[9] In 2007 we conducted a bathymetric survey of the axial valley and northern rift valley wall of the $85^{\circ} \mathrm{E}$ volcanic center using I/B Oden's Kongsberg EM $1201^{\circ} \times 1^{\circ}$ multibeam sonar. Bathymetric data were collected while the ship drifted in the pack ice (with engines silent) along overlapping tracks at the $85^{\circ} \mathrm{E}$ segment. The resulting lownoise, high-density multibeam soundings allowed us to construct a $30 \mathrm{~m}$ resolution bathymetric grid of the study area (Figure 1b). This new bathymetric grid was merged with the International Bathymetric Chart of the Arctic Ocean (IBCAO) Version 2.0

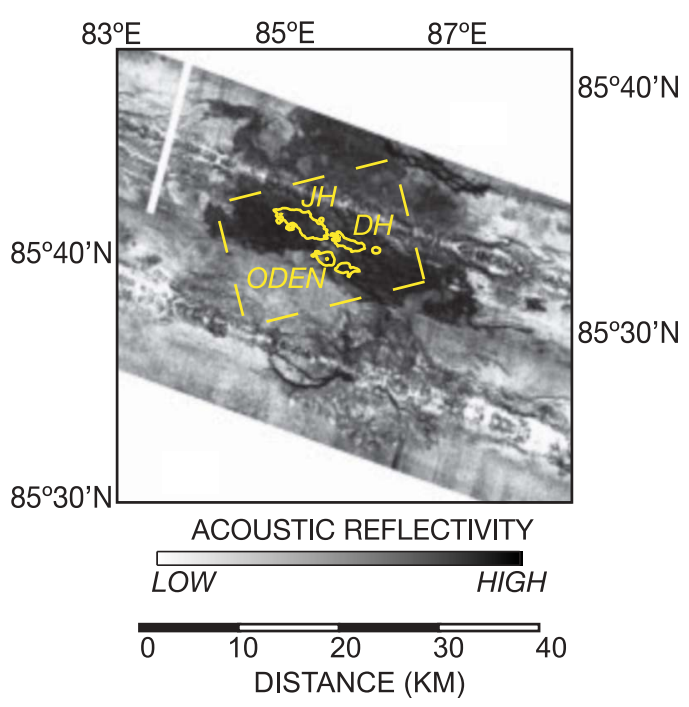

Figure 3. SCICEX 1999 acoustic reflectivity map. A SCICEX 1999 acoustic reflectivity map that encompasses our study area (yellow box) shows an $\sim 30 \mathrm{~km}$ long region of high reflectivity [Edwards et al., 2001]. Our study area, including Jessica's Hill (JH), Duque's Hill (DH), Oden Volcano, and Loke Volcano fall within the zone of high reflectivity. 
[Jakobsson et al., 2008]. IBCAO 2.0 was in turn compiled using all available bathymetric data in the Arctic Ocean at the time of compilation, including soundings collected in the Gakkel Ridge area during the SCICEX 1999 and AMORE cruises. These data are available through Marine Geoscience Data System, the NOAA IBCAO website, and at http:// oden.geo.su.se/AGAVE2007.php [Jakobsson et al., 2008; Ryan et al., 2009].

\subsection{Seafloor Imagery, Seawater Measurements, and Rock Samples}

[10] Near-bottom imaging surveys were conducted with the deep-towed CAMPER vehicle, a towed, fiber-optic vehicle that operates at altitudes of 1.5 to $3 \mathrm{~m}$ above the seafloor. The CAMPER vehicle collected digital video and still imagery, measurements of near-bottom water properties, and geologic and biological samples on thirteen deployments at the $85^{\circ} \mathrm{E}$ site (Figure $1 \mathrm{~b}$ ). Because the vehicle is operated from an idle ship within the pack ice, its trajectory over the bottom is controlled by the direction and flow of the local ice pack, with typical drift speeds of 0.15 to 0.3 knots. The position of CAMPER on the seafloor was determined from ship GPS navigation, corrected for ship heading, and assuming an essentially vertical wire from the ship to the towed vehicle [cf. Stranne et al., 2010].

[11] The multipurpose vehicle was outfitted with five standard and high-definition video cameras that streamed real-time video to the ship via a fiber-optic cable. Conductivity-Temperature-Depth (CTD) and an $E h$ sensor for measuring the oxidation-reduction potential of seawater were also mounted on the vehicle in order to identify the presence of reduced (i.e., fresh) hydrothermal fluids. The $E h$ values presented in this paper are the measured Pt electrode voltage against the $\mathrm{Ag} / \mathrm{AgCl}$ reference electrode in saturated $\mathrm{KCl}$ solution. Eh measurements can be converted to the redox potential of seawater, i.e., against the standard or normal hydrogen electrode (SHE or NHE) by applying a temperature correction, but we do not make the conversion because the electrodes on the moving CAMPER platform never reach equilibrium with seawater [Nakamura et al., 2000]. Measured thermal anomalies represent potential temperature anomalies derived from absolute temperature, pressure and salinity measurements adjusted for an adiabatic displacement to a reference pressure of 3000 dbars [Bryden, 1973; Fofonoff and Millard, 1983; Baker et al., 1994]. Approximately $4 \mathrm{~kg}$ of unconsolidated volcaniclastic deposits, Sample 12-1 and Sample 13-1, were sampled from two sites on the axial valley seafloor at $4000 \mathrm{~m}$ and $4116 \mathrm{~m}$ water depths respectively using a suction sampler on CAMPER (Figure 1b). Larger rock samples were also grabbed from 7 locations [Shaw et al., 2010].

\subsection{Volcanic Deposits at the $85^{\circ} \mathrm{E}$ Site}

[12] We logged seafloor volcanic, tectonic, and biological features in approximately $55 \mathrm{~h}$ of HD seafloor footage over 17.5 linear kilometers of seafloor co-registered with high-resolution bathymetric data $(\sim 5 \mathrm{~km} \times 10 \mathrm{~km}$ area, Figure $1 \mathrm{~b})$. Observations were made in seven primary categories, each with multiple subcategories: lava surface morphology, coloration, ornamentation, broken/intact lava surfaces, volcaniclastic deposit thickness, microbial mat coverage, and presence/absence of macrobiology (Figures S1-S7 in the auxiliary material). ${ }^{1}$ These observations allowed us to identify lava flow contacts and flow directions, relative eruption ages, possible source vents, and relationships between volcanic processes, hydrothermal discharge, and biological colonization.

[13] We categorized lava surface morphologies as pillow, lobate, or sheet flow [e.g., Ballard et al., 1975, 1979; Lonsdale, 1977a, 1977b; Bonatti and Harrison, 1988; Fundis et al., 2010], which are thought to reflect increasing volume flux [Fink and Griffiths, 1992; Gregg and Fink, 1995]. In addition, we logged the orientation of lineations, folds, or pillow/lobate elongation, which can be related to the direction of lava transport [e.g., Chadwick et al., 2001; Garry et al., 2006]. We logged lava colorations (black/glassy versus orange/oxidized), and the presence or lack of ornamentation (delicate fingers or buds), as indicators of relative age. We did not detect any pelagic sediment, which is commonly used as an indicator of relative lava age in midocean ridge environments [e.g., Cann and Smith, 2005], in our study area. Low biological productivity beneath the sea ice limits sedimentation rates but pelagic sediment has been observed in the region [Vogt et al., 1979; Thiede et al., 1990]. Recent volcanism may overprint pelagic sediments.

[14] We categorized volcaniclastic deposit coverage, which was present in all imagery, as light, medium, or thick. 'Light' coverage represents lava surfaces that are visible through a light "dusting" of volcaniclastic material. 'Medium' coverage represents surfaces that are not visible through the

\footnotetext{
${ }^{1}$ Auxiliary materials are available in the HTML. doi:10.1029/ 2012 GC004187.
} 
volcaniclastic material, with a deposit thickness of a few centimeters. 'Thick' coverage represents surfaces where volcaniclasts pile on lava surfaces with a thickness of up to $\sim 10 \mathrm{~cm}$, and fill in void spaces between seafloor features with tens of centimeters of relief. Potential controls on submarine volcaniclastic deposit thickness include the age of the underlying surface and the proximity to the source regions [e.g., Barreyre et al., 2011]. Volcaniclastic material was sampled from two sites (Figure 1b), as described in section 4.2.2.

[15] We logged the presence or absence of biological organisms and whether the observed organisms are motile or sessile. Sessile organisms, which are fixed to the seafloor, included sponges and anemones. The presence or absence of microbial mats was also logged. Motile organisms, which are free to move to available food sources, include fish, an octopus, shrimp, and amphipods. The presence of sessile organisms provides some indication of relative seafloor (i.e., eruption) age because it is set to zero when a surface is repaved during an eruption, and grows over time as an area is colonized [Shank et al., 1998]. The presence of microbial mats can be used as a proxy for identifying zones of active hydrothermal discharge because these organisms derive metabolic energy by oxidizing hydrothermal fluids [Helmke et al., 2007].

\section{Results}

\subsection{Seafloor Geology}

[16] The $85^{\circ} \mathrm{E}$ segment of the Gakkel Ridge has a $12-15 \mathrm{~km}$ wide and $1.8 \mathrm{~km}$ deep rift valley morphology with an average valley floor depth of $3870 \mathrm{~m}$, and a maximum depth of $4351 \mathrm{~m}$. Linear volcanic ridges and cones (many of which have large central craters) are the predominant constructional volcanic features inside the axial valley and rise several hundred meters above the valley floor. These features are concentrated along two axisparallel lineaments located in the central portion $(5 \mathrm{~km})$ of the axial valley, with the notable exception of a large (1250 m diameter) cone located on an apparent fault terrace about halfway up the northern rift valley wall (Figure 1b). Only 12 faults and fissures are observed along 20 linear $\mathrm{km}$ of track (Figure 7). No peridotite lithologies are observed on the seafloor.

[17] The near-bottom CAMPER transects provide coverage over portions of the two intravalley volcanic lineaments, including Oden and Loke volcanic cones and Jessica's Hill and Duque's Hill volcanic ridges. Oden and Loke are located on the southern lineament; Jessica's Hill and Duque's Hill are located on the northern lineament (the lineaments are offset by $2-3 \mathrm{~km}$, Figure $1 \mathrm{~b}$ ). The lava morphology (lobate vs sheet), coloration (orange/ altered vs glassy), and volcaniclastic deposit thickness observed along the CAMPER tracklines are shown in Figure 4. Talus and pillow lavas are the dominant deposit types observed in the study area. Pillow lavas are observed along $44 \%$ of the trackline. Some lobate and sheet flows are observed on the volcanoes ( $14 \%$ of the trackline) and ridgelines $(<1 \%)$ (Figures $\mathrm{S} 1-\mathrm{S} 7$ in the auxiliary material). Observations of glassy (i.e., young) lavas are restricted to the Oden and Loke Volcanoes, where higher effusion rate sheet flows are also found. The linear ridges appear to be older volcanic features consisting largely of oxidized and broken pillow basalts. Seafloor talus blocks cover the steep slopes and the bases of fault scarps. Glassy, unconsolidated, volcaniclastic material was observed on all surfaces regardless of apparent age or morphology (96\% of trackline). Volcaniclastic deposits are thickest on the Duque's Hill and Jessica's Hill linear ridges, thinnest on the Oden and Loke volcanic cones, and are present as a light 'dusting' on the youngest (i.e., glassy) lavas. Microbial mats are observed over $5.5 \%$ of the trackline.

\subsubsection{Oden Volcanic Cone}

[18] Oden is one of several volcanic cones (including Loke and Thor) that constitute the SE end of the southern volcanic lineament (Figure 1b). Three of the CAMPER deployments pass over the Oden volcanic cone, and a fourth passes just to the east (Figure 1b), providing some of the densest track line coverage in our survey area. The flattopped cone is $1400 \mathrm{~m}$ in diameter and $170 \mathrm{~m}$ tall, with a $600 \mathrm{~m}$ wide by $70 \mathrm{~m}$ deep central crater (Figure 5). Our deployments pass over the edges of the crater, and orange-yellow microbial mats blanket much of the seafloor in this area (Figure 5c). Where visible, the seafloor within the crater is covered with talus blocks and a thin $(<1 \mathrm{~cm})$ coating of glassy volcaniclastic material (Figure $5 \mathrm{~d}$ ).

[19] On the crater rim we observe mostly pillow lavas and lobate flows, including obvious contacts between older flows and fresh, glassy surfaces (Figures 5e and 5f). Some of the lavas with orange, altered, surface colorations have retained delicate ornamentations, suggesting that coloration does not necessarily correlate with eruption age. We also observed a glassy, ropy sheet flow with a flow 


\section{A. LOBATE (•) AND SHEET FLOWS (॰)}

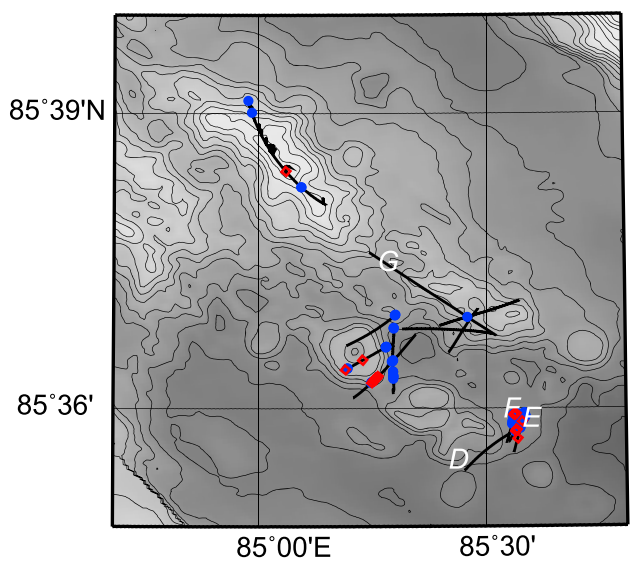

B. PILLOW LAVAS - ALTERED (•) / GLASSY ( $\bullet)$

\section{VOLCANICLASTIC DEPOSIT THICKNESS}
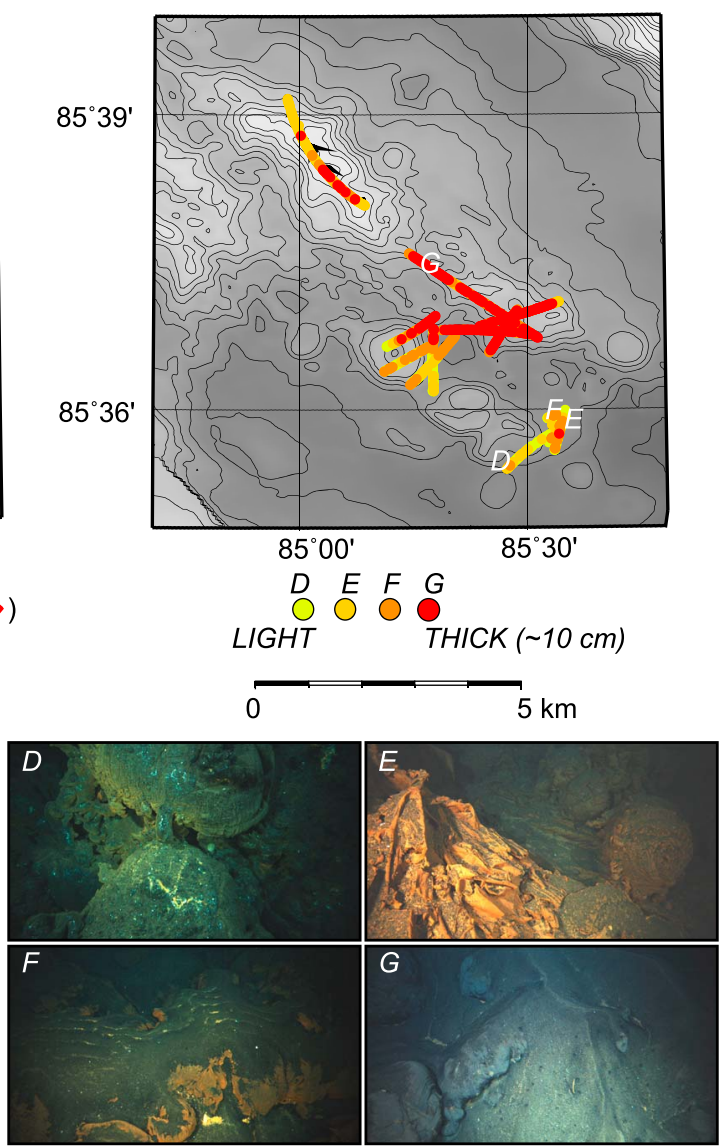

$85^{\circ} 00^{\prime}$

$85^{\circ} 30^{\prime}$

Figure 4. Distributions of lavas and volcaniclasts. (a) A bathymetric map shows that lobate flows (dots) are observed on all four seafloor features examined in digital imagery. Lobate flows (e.g., Figure 4f) are found at the ridge crests of Jessica's Hill and Duque's Hill axial volcanic ridges. They are also abundant on Oden Volcano and the northern apron of Loke Volcano. Sheet flows (diamonds; e.g., Figure 4e), products of more effusive eruptions, are also abundant on the volcanic cones. (b) Oxidized or weathered pillow flows (dots) are observed on all seafloor features, as well as the seafloor in the depression between the two axial valley trends. Glassy, fresh, and highly ornamented lavas (diamonds; e.g., Figure 4d) are only observed on the steep slopes and summits of Oden and Loke Volcanos and represent the youngest eruptive products in the study area. (c) Volcaniclastic deposits of variable thickness are observed throughout the study. (d-g) Coverage from a light dusting to a thick cover $(\sim 10 \mathrm{~cm})$ that buries lava surfaces and fills in crevices between rocks on the seafloor. Duque's Hill has the thickest volcaniclastic cover. "Fresh" lavas on Oden and Loke Volcanoes are lightly dusted with volcaniclastic material.

orientation radial to the center of the volcano on the crater rim.

[20] The outer walls of the cone consist largely of pillow tubes elongated in the downslope direction, lobate flows, and talus. In some places the pillow tubes are glassy and ornamented, in other places they have orange surfaces. The talus slope on the NE wall is interrupted by an orange-stained lobate flow (with a thin microbial coating). The abrupt nature of this contact and the lack of talus on the lobate flow indicates that the flow is a relatively young feature that erupted from within the talus field.
[21] The marginal regions around Oden exhibit a mix of orange-stained flows and fresh, glassy lavas. The $4000 \mathrm{~m}$ deep bathymetric saddle between Oden and Duque's Hill contains weathered, unornamented, pillow lavas and talus breccia, with no evidence of recent volcanic activity. On the $4100 \mathrm{~m}$ deep platform between Oden and Thor we observe pillow lavas and an ornamented, orange-stained, lobate flow. Glassy, elongate, ornamented pillow lavas were observed at the base of the Thor volcanic cone. 
A.

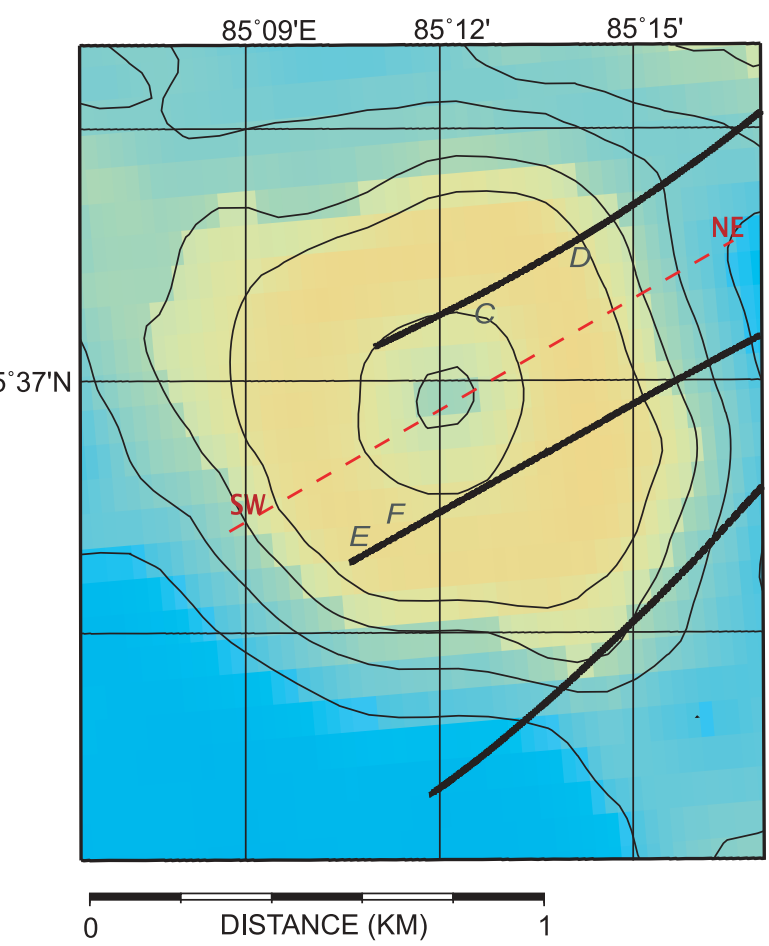

B.

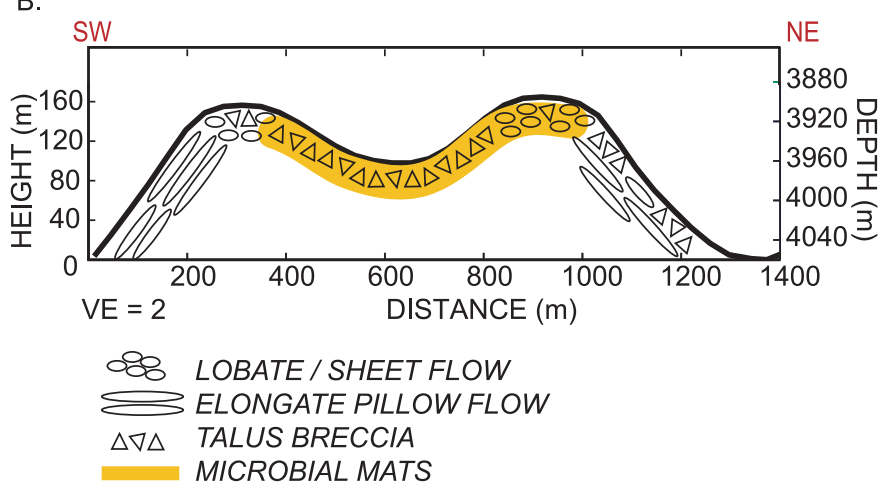

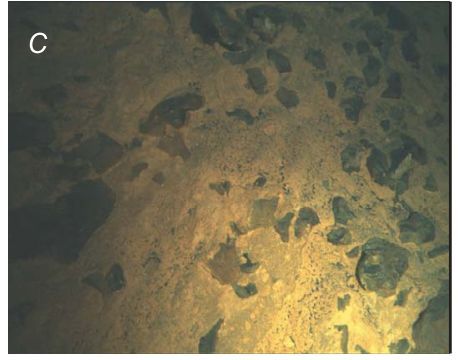
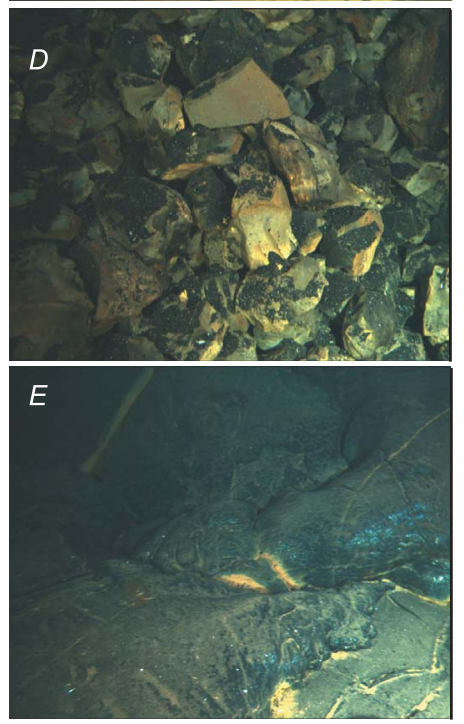

$F$

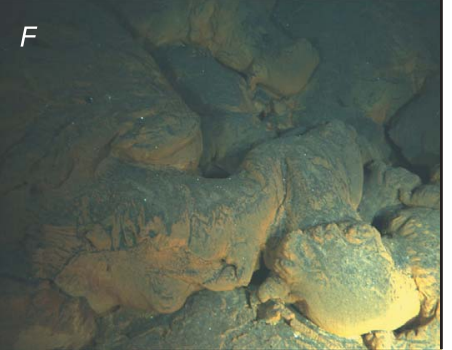

Figure 5. (a) Oden Volcano Map view and (b) profile of Oden Volcano-a $1600 \mathrm{~m}$ diameter volcano with $\sim 200 \mathrm{~m}$ of relief and an $80 \mathrm{~m}$ deep $\times 700 \mathrm{~m}$ wide circular crater. (c) Talus and microbial mats in the crater. (d) Talus ejecta on the flank of the volcano covered in a moderate thickness of large pyroclasts. (e) Fresh, glassy lobate flow with evidence of hydrothermal alteration at edges. (f) Weathered, elongate pillow flow with moderate pyroclastic coverage.

\subsubsection{Loke Volcanic Cone}

[22] The Loke volcanic cone is $1200 \mathrm{~m}$ in diameter with $150 \mathrm{~m}$ of vertical relief from a basal depth of more than $4000 \mathrm{~m}$. One CAMPER track line passed over the SE side of the structure, and two more surveyed the area immediately NE of the cone. The southeastern wall of the cone appears to have been breached by a lava flow and/or collapsed such that the volcanic edifice is horseshoe-shaped (Figure 1b). The bathymetric "apron" that extends outwards from the volcano is comprised of multiple, low-relief, lava flows with obvious contacts that extend radially from the base of the cone. At the edge of the apron, over $500 \mathrm{~m}$ from the slopes of Loke, we found black, glassy pillows. Within the apron we observed a $>50$-m-wide lava channel that displayed typical morphologies of lineated sheets at the channel center surrounded by chaotic, jumbled textures and bordered by lobates (Figure 6) [Soule et al., 2005; Garry et al., 2006]. Sheet flows had hackly, chaotic, lineated, and ropy surface textures. On the volcanic cone some glassy lava surfaces (Figure 4d) were overlain by microbial mats. 


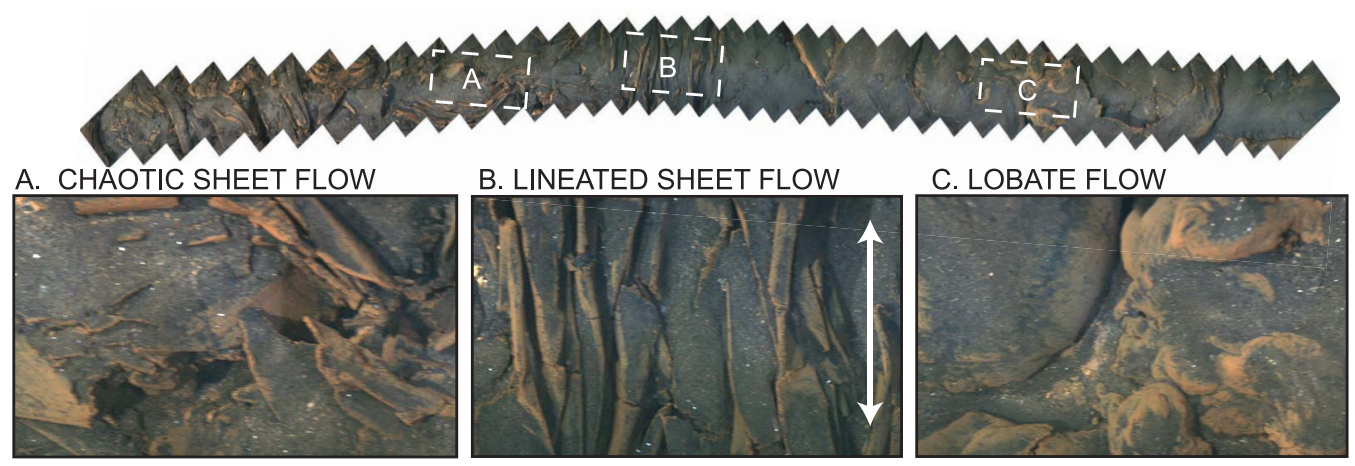

Figure 6. Sheet flow on Loke's apron Mosaic of a sheet flow on Loke's apron (see Figure 1b). Altered lavas covered in a moderate thickness of volcaniclastic deposits show a transition from chaotic sheet flow to lineated sheet flow, boarded by lobates. The white arrow in Figure $6 \mathrm{~b}$ denotes the approximate orientation of flow.

\subsubsection{Jessica's Hill and Duque's Hill Linear Ridges}

[23] Jessica's Hill is $5.5 \mathrm{~km}$ long, $1.8 \mathrm{~km}$ wide, and $0.4 \mathrm{~km}$ high with a peak at $3650 \mathrm{mbsl}$; Duque's Hill is $2.5 \mathrm{~km}$ long, $1.2 \mathrm{~km}$ wide, and $0.125 \mathrm{~km}$ high with a peak at $3820 \mathrm{mbsl}$. Both of these features are located on the northern volcanic lineament in the rift valley, and appear to be volcanic constructional features similar to axial volcanic ridges described on the slow-spreading Mid-Atlantic Ridge [Ballard and van Andel, 1977; Ramberg and van Andel, 1977; Smith and Cann, 1990, 1992; Searle et al., 2010]. The ridges consist primarily of orangestained, broken, pillow basalts and talus, and we did not observe any evidence of fresh eruptive products (i.e., glassy surfaces) on these features. Some pillows were ornamented, but all had dull or oxidized surfaces. The steep slopes of the ridges are characterized by elongate pillow lavas, and steep, 9-10 $\mathrm{m}$ high scarps consisting of fractured pillows were observed in six places. Both Jessica's Hill and Duque's Hill are covered with moderate to thick layers of volcaniclastic deposits, with the thickest coverage on Duque's Hill where the volcaniclasts completely bury the lavas and talus in many places (Figure 4g).

\subsection{Volcaniclastic Deposits}

\subsubsection{Deposit Thickness}

[24] Our qualitative evaluation of volcaniclastic layer thickness varied from a light dusting (Figure 4d) to up to $\sim 10 \mathrm{~cm}$ thick cover (Figure $4 \mathrm{~g}$ ) along the seafloor tracks (Figure 4c). Volcaniclastic deposits were thickest on the linear ridges and in the depression between the two volcanic lineaments, and thinnest on the glassy, unaltered lava flows identified on
Oden and Loke Volcanoes. Abrupt transitions in volcaniclastic deposit thickness were observed on the seafloor on the apron of Loke and on the flanks of the volcanoes, and often corresponded with other indicators of flow contacts between lavas of different relative ages (morphology, coloration). Volcaniclasts were present on lava surfaces of all ages and on nonvolcanic surfaces (e.g., talus slopes) suggesting that they were not derived from quench granulation of lava flows [e.g., Batiza et al., 1984]. In addition, volcaniclasts were piled on the tops of pillows high on ridgelines of Duque's Hill and Jessica's Hill, indicating deposit by fall rather than flow. Although difficult to quantify, there appeared to be a tendency for the clast layer to thicken downslope on the flanks of the linear ridges, suggesting some post-depositional downslope movement of material.

[25] In general, there is a correlation between the apparent (relative) age of the lava flows and the thickness of the volcaniclastic deposits, with the freshest-looking lavas being covered with a light dusting of material and the oldest-looking lava surfaces being covered with the thickest deposits. This suggests that the volcaniclasts have been deposited progressively over time, and that they are buried by younger lava flows. In most places it was not possible to discern any systematic spatial variations in clast grain size, but on the NE side of Oden Volcano the clast grain size appeared to increase toward the crater, and the largest clasts observed during our surveys were observed on the crater rim, suggesting that the crater may have been a source vent for volcaniclastic material. Within the crater, a light dusting of volcaniclastic material sat on, or was embedded into, the microbial mats, and could be observed on top of talus blocks protruding from the mats as well (Figure $5 \mathrm{c}$ ). 

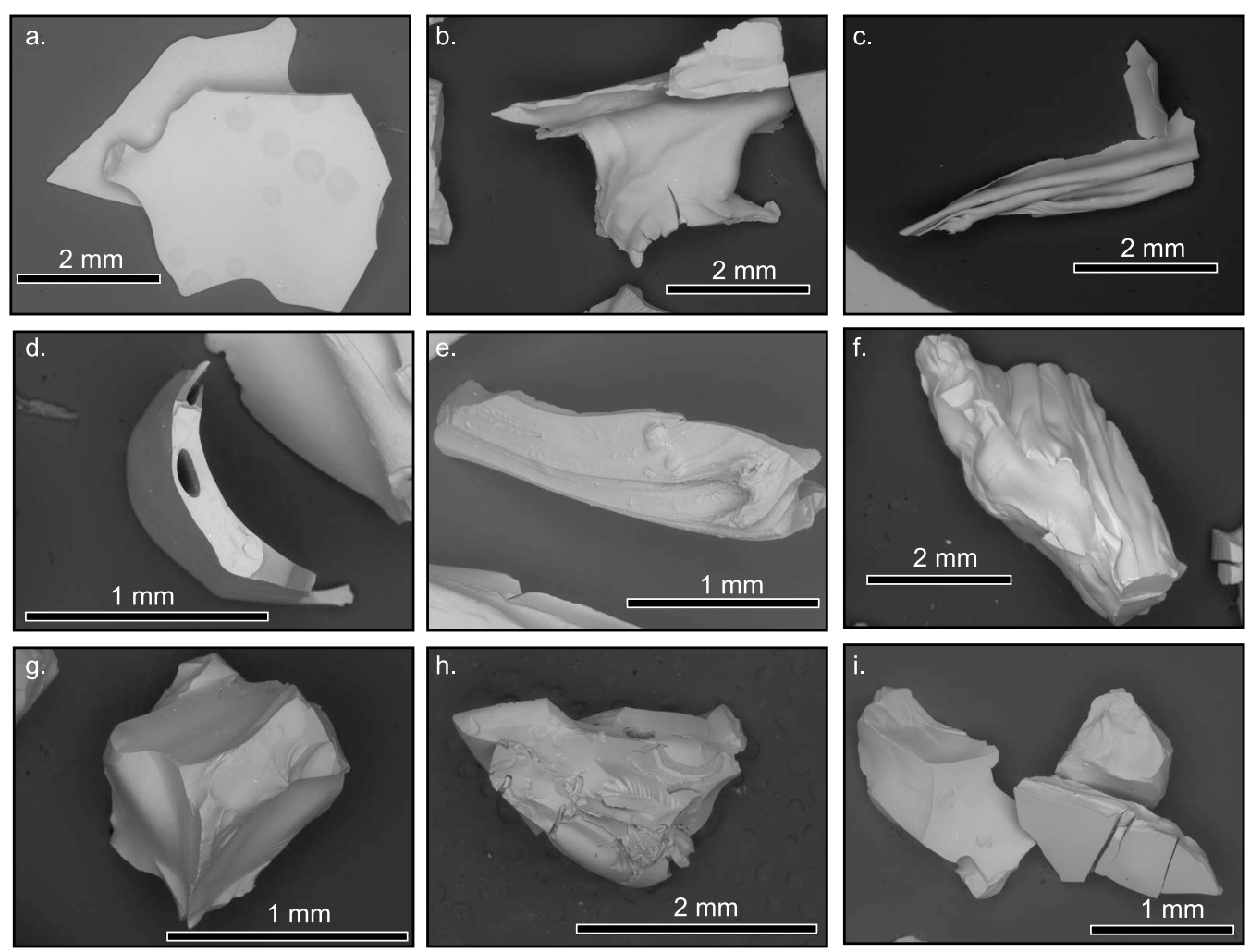

Figure 7. SEM images of volcaniclast morphologies. (a-c) Limu o Pele, or bubble-wall fragments and fluidal morphologies. (d-f) Platy clasts with crystalline inclusions and elongate vesicles. (g-i) Blocky dense fragments dominate the samples.

\subsubsection{Clast Morphologies}

[26] We analyzed volcaniclastic material from two suction samples acquired during our CAMPER surveys. Sample 12-1 was collected from the saddle between Jessica's Hill and Duque's Hill AVRs at a depth of $4000 \mathrm{~m}$, and Sample 13-1 was collected from thick deposits at the base of Duque's Hill at a depth of $4116 \mathrm{~m}$ (Figure 1b). Grain size analysis revealed clasts from fine volcanic ash $(<0.149 \mathrm{~mm})$ to greater than $4 \mathrm{~mm}$ in length. Mean grain size was consistent with volcaniclastic deposits from the slow-spreading Mid-Atlantic ridge [Eissen et al., 2003]. Details of grain-size sorting are described by Barreyre et al. [2011].

[27] We examined a representative sample of $\sim 1200$ volcaniclasts by stereo microscope and SEM for morphology and other characteristics including apparent age (juvenile or non-juvenile), material (glass, biogenic, or silt), and morphology (blocky, platy or tabular, or sheet-like). Both samples consist almost entirely of juvenile clasts of glassy basalt. Slightly vesicular blocky fragments dominate the deposits (Figures 7g-7i; see also Figures S8 and S9 in the auxiliary material). A moderate fraction of fragments $(<22$ wt. $\%$ and $<12$ wt. $\%$ for Samples $12-1$ and 13-1, respectively) are limu o pele bubble wall fragments [Mattox and Mangan, 1997; Maicher and White, 2001; Clague et al., 2009]. Some fragments preserve elongate vesicles or tubes, also representative of rapid quenching. Most vesicles imaged are not interconnected, indicating that the magma had limited permeability, which could facilitate the development of gas slugs [Namiki and Manga, 2008; Polacci et al., 2008; Schipper and White, 2010].

[28] Bubble-wall fragments are flat, curved, or complexly folded (Figures 7a-7c). We also observed tubelike structures (Figure 7d), triple junctions, elongated vesicles, and surface textures preserved by rapid cooling (Figure 7a) [Clague et al., 2009]. Surfaces of limu o Pele fragments range from smooth to bumpy, the latter due to small inclusions of crystals and bubbles. No Pele's hair or rod shapes are evident in the samples. Dense, blocky volcaniclasts commonly display conchoidal fractures indicative of fracture at temperatures lower than the glass-transition temperature [Maicher et al., 2000]. There is a very small 
A.

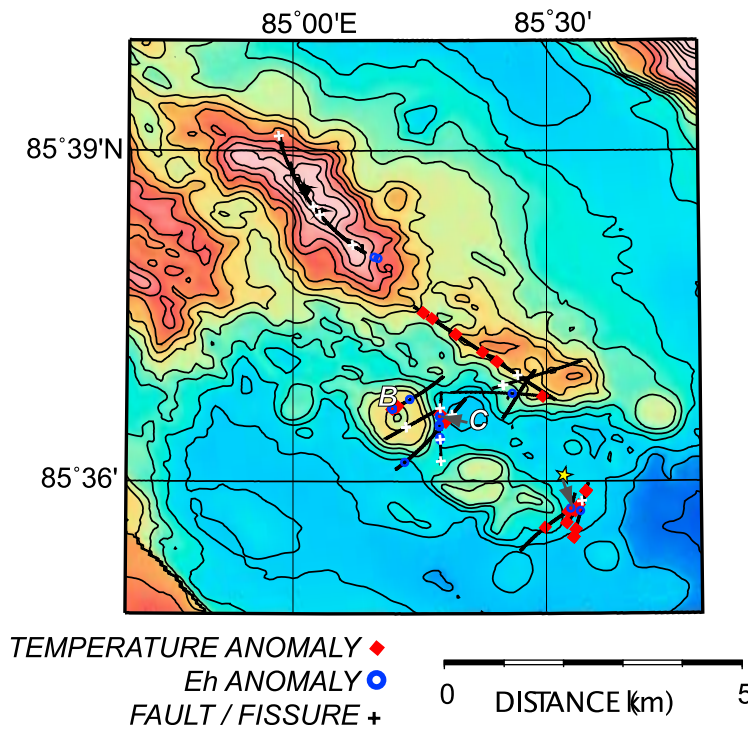

B. SEAWATER ANOMALIES ON ODEN

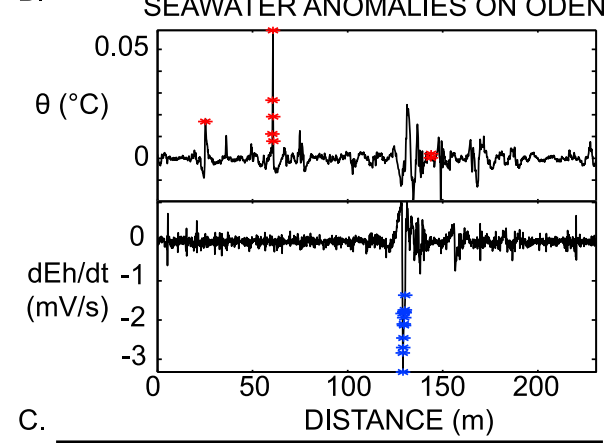

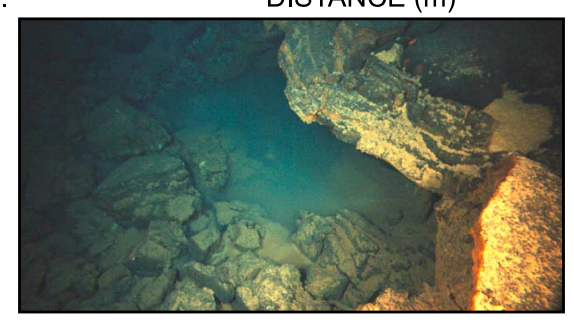

Figure 8. Near-bottom seawater anomalies. (a) A map shows locations of near-seafloor seawater temperature and Eh anomalies and faults and fissures. CTD data were not collected on Jessica's Hill. The yellow star denotes a visual observation of cloudy fluid $90 \mathrm{~m}$ above the seafloor of Loke's apron. (b) Concurrent measurements of potential temperature and $E h$ records during deployment DCS-15 on Oden show temperature and $E h$ anomalies (diamonds and dots, respectively) detected within tens of meters of one another on the edifice. (c) Cloudy fluid emanates from beneath an overhanging ledge on Oden Volcano where temperature and Eh anomalies are detected. Yellow microbial mats coat the rocks.

component of crystalline and altered basalt rock in the samples but it is not clear whether these are from the volcaniclastic deposits or originated from underlying intact lava flows. Free olivine containing melt inclusions [Shaw et al., 2010] and a small component of altered clasts with orange colorations, which may be palagonite, were also observed.

\subsection{Near-Bottom Water Column Anomalies}

[29] As described in section 3.2, the CAMPER vehicle was equipped with sensors to detect near-bottom water column anomalies in temperature and $E h$, which can be used to detect regions of hydrothermal discharge [Baker et al., 1994; Nakamura et al., 2000].

[30] Near-bottom (1-3 m above the seafloor) temperature anomalies $\left(\delta \theta\right.$ of $\left.0.005-0.019^{\circ} \mathrm{C}\right)$ were observed over Duque's Hill, Oden Volcano, and Loke Volcano (Figure 8; see also Table S1 in the auxiliary material). Twenty-three $E h$ anomalies were detected on the flank of Oden Volcano. No anomalies were detected on the seafloor between the volcanic lineaments.

[31] Many of the Eh anomalies measured on Oden Volcano were concurrent with observations of dense microbial mats (Figure 9). One or two near- bottom Eh anomalies were detected over Duque's Hill, Jessica's Hill, and the apron of Loke Volcano. Oden and the apron of Loke are the only places where temperature and $E h$ anomalies were colocated. Within the crater of Oden Volcano, the tips of orange-stained talus blocks protruded through near-continuous microbial mat (Figure 5c) and seawater measurements identified temperature and $E h$ anomalies within $20 \mathrm{~m}$ of one another (Figure $8 \mathrm{~b}$ ). On the flanks of the volcano, in one collapse pit, a pool of cloudy water was observed (the only place in our imagery where hydrothermal fluids could be observed discharging from the seafloor) simultaneously with a strong $E h$ anomaly (Figure 8c) and observations of microbial mats (Figure 9). Loke Volcano also hosted extensive microbial mats. On the apron of Loke Volcano, temperature and $E h$ anomalies were detected in the vicinity of a fissure and cloudy seawater was observed at $90 \mathrm{~m}$ above the seafloor during ascent of the CAMPER vehicle. On Duque's Hill no microbial mats were observed, but near-seafloor temperature and $E h$ anomalies were measured at several areas along the steep slopes. We observe $E h$ anomalies on Jessica's Hill and south of Oden in areas where microbial mats are not observed, suggesting that $E h$ anomalies have a hydrothermal source and are not generated by the microbial mats. 

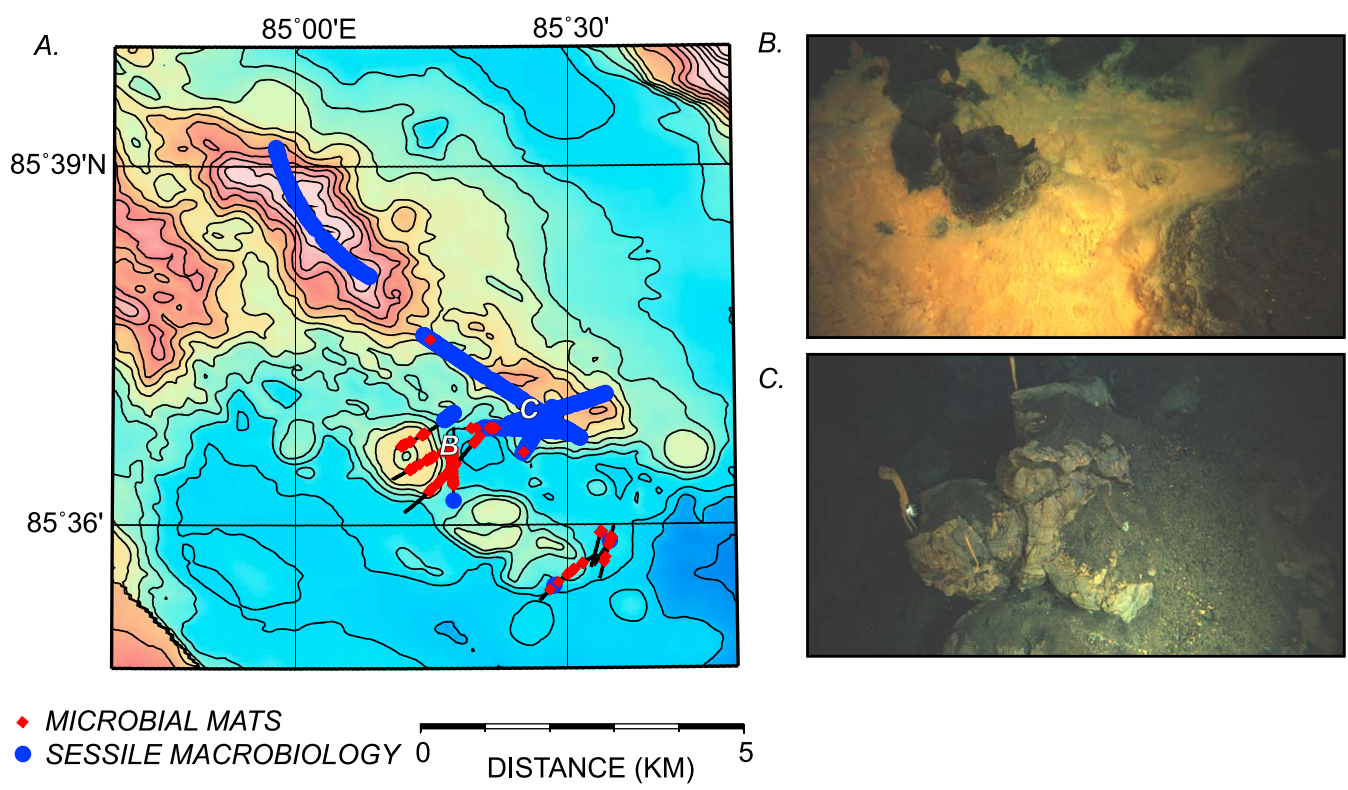

- MICROBIAL MATS

DISTANCE $(\mathrm{KM})$

Figure 9. Locations of sessile biology. (a) A bathymetric map shows locations of microbial mats and sessile megafauna. Locations of (b) microbial mats correspond with areas of diffuse hydrothermal venting and observations of the youngest eruptive products on Oden and Loke Volcanoes. Sessile macrofauna such as (c) sponges and anemones are abundant on the relatively older seafloor of the axial volcanic ridges.

[32] Temperature and Eh anomalies (detected by CTD 'tow-yos') were ubiquitous higher in the water column over wide portions of the rift valley [Stranne et al., 2010], and modeling of these data indicated that there are up to six distinct sites of hydrothermal discharge on the seafloor within the axial valley. Inferred discharge sites from water column data agree with sites of our near-bottom anomalies, and near-seafloor measurements show that water anomalies are detected over 100's of meters along the volcanic cones and ridges.

\section{Discussion}

[33] We assign relative ages of flow units using the abundance of volcanic glass, the degree of alteration of lava surfaces, and the sediment cover [e.g., van Andel and Ballard, 1979]. These subjective criteria are not easily quantified and are affected by factors other than age alone. For example staining and palagonitization are useful indicators of age, but the presence of diffuse hydrothermal venting and microbial mats may also alter lava surface coloration. Although volcaniclastic deposition is likely not continuous in time or space, we use abrupt transitions in volcaniclastic thickness as a useful tool to support relative age inferences from other observations. The thickness of a submarine volcaniclastic deposit depends on the age of the lava flow on which it rests, proximity to the source vent, and to a lesser degree, post-depositional transport [e.g., Barreyre et al., 2011]. The relative abundance of sessile biology also provides an indication of seafloor age because colonization begins at the time of lava flow emplacement and appears to progress predictably with time [Shank et al., 1998].

\subsection{Recent Eruptions at $85^{\circ} \mathrm{E}$}

[34] Correlated lava surface morphology transitions and relative age indicators (e.g., staining, presence/ absence of fine ornamentation, volcaniclastic deposit thickness) suggest that the survey area has experienced numerous eruptions from volcanic vents scattered throughout the axial valley (Figure 10). Lava surfaces on the Oden volcanic cone vary from glassy, sometimes ornamented surfaces to orange-stained (Figures $5 \mathrm{e}$ and $5 \mathrm{f}$ ). Although the extent of surface coloration may indicate eruption age, we note that the presence of hydrothermal anomalies in the area may expedite the lava surface alteration process, making pillows appear "prematurely" orange [Stroncik and Schmincke, 2002]. Alternatively, the microbial mats, which appear similar to mats composed of Feoxidizing bacteria on Loihi Volcano [e.g., Emerson and Moyer, 2002; Edwards et al., 2011] may be the primary cause of coloration [e.g., Staudigel and Clague, 2010]. As such, we are cautious when interpreting flow contacts and require variations in 


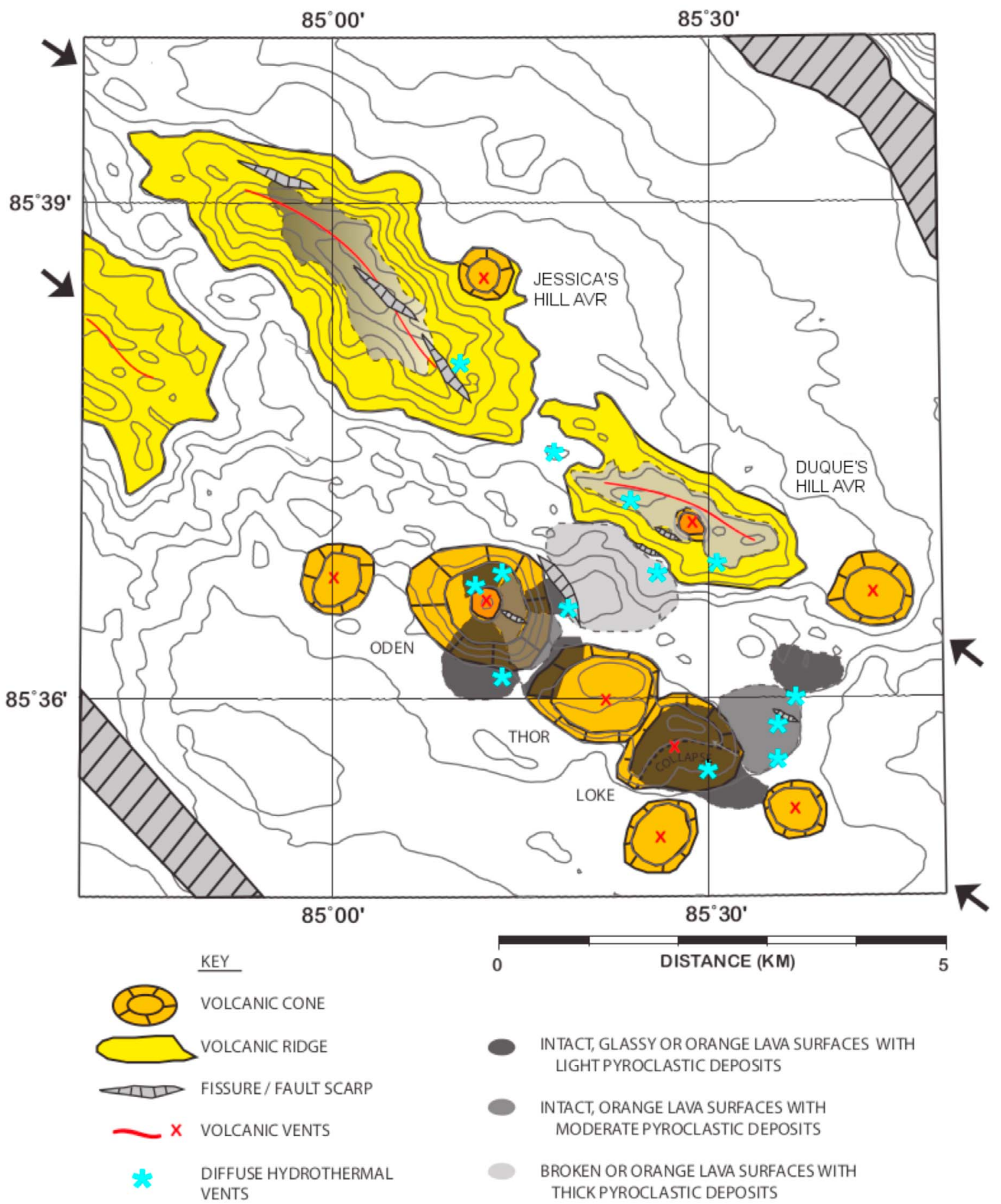

Figure 10. Interpretive map of volcanic features, small-volume effusive lava flows, pyroclastic deposits, and possible volcanic vents extrapolated from near-seafloor observations and bathymetry.

coloration to be accompanied by variations in morphology, degree of ornamentation, and volcaniclastic thickness.

[35] To better constrain relative ages of eruptions on Oden Volcano, we evaluate the distribution of volcaniclastic material on lava surfaces. Although volcaniclastic deposition is likely not continuous in time or space, differences in volcaniclastic thickness are a useful tool to support relative age inferences from other observations. For example, orangestained lava pillows on Oden's eastern rim are 
covered in a moderate thickness of volcaniclastic deposits, while the unstained, glassy, ornamented pillows on Oden's southern slopes have only a light dusting of volcaniclastic deposits. Oden's northern rim is also covered in ornamented pillows with a light dusting of volcaniclastic deposits, but lava surfaces on the northern rim are orange-stained, possibly due to rapid alteration by interaction with diffuse hydrothermal fluids detected in the area. Abrupt changes in volcaniclastic deposit thickness must represent contacts between flow units rather than spatial variations in distance from an explosive source, which would result in more gradual changes in deposit thickness. Thus Oden is constructed of products of at least two eruptions of distinct ages, one being very recent and possibly after, or coincident with, the emplacement of volcaniclastic deposits.

[36] A distinct contact was also observed between the relatively older, moderately volcaniclast-covered lava surfaces on Oden and lightly dusted, glassy, ornamented pillows oriented downslope on Thor Volcano, which look similarly fresh to glassy flows on Oden. On Loke Volcano fresh, glassy lava surfaces in conjunction with the light distribution of volcaniclasts suggests that the elongate pillow lavas that mantle the flanks of the volcanic cone erupted more recently and overlay the eruptive units on the apron. The eruptive apron is composed of high effusion rate sheet flows, is pervasively stained, and has accumulated more volcaniclastic material on its surface. Orientations of sheet flows suggest that lavas were transported radially from the central crater of the cone.

[37] We infer from the coincidence of glassy, elongate pillow lavas with ornamental buds, and a thin dusting of volcaniclastic deposits that Oden, Thor, and Loke Volcanoes are sites of the most recent eruptions. The extent of individual eruptive units are poorly constrained, but the identification of a few flow contacts suggest aerial extents on the order of $\sim 33 \%$ or less of the cone areas $\left(\sim 3 \mathrm{~km}^{2}\right)$. Given their thin volcaniclastic cover and fresh, glassy surfaces, these young flows on the volcanoes were emplaced slightly before or at the time of the most recent volcaniclastic eruption that is presumed to have occurred in 1999 [Müller and Jokat, 2000; Tolstoy et al., 2001]. Multiple, small-volume, eruptions on these volcanoes thus characterize the most recent effusive volcanic activity at $85^{\circ} \mathrm{E}$.

[38] Duque's Hill and Jessica's Hill are axial volcanic ridges (AVRs) constructed from multiple effusive eruptions that appear to have occurred earlier than the recent eruptions on the southern lineament. Both ridges are dominated by talus slopes, oxidized pillows, fractured seafloor, abundant sessile macrofauna, and a lack of microbial mats. The absence of sessile macrofauna on Oden and Loke Volcanoes and their presence on Jessica and Duque's Hills suggest that eruptions on the AVRs may be older than any of the volcanoes on the southern lineament. Despite their apparent older age, few faults and fissures are observed, although the presence of steep talus slopes provides indirect evidence of faulting. Jessica's Hill has some lobate flows at the ridgeline, indicating moderate flux eruptions. However, pillow eruptions dominate the lava morphology of both ridges. Both ridges are covered in a moderate to heavy thickness of volcaniclastic deposits. This is consistent with older eruption ages and hence longer periods of volcaniclast accumulation or proximity to a source.

[39] A relatively younger age for southern lineament volcanoes is supported by the abundance of near-seafloor temperature and $E h$ anomalies, and the absence of sessile macrofauna (Figure 9). Oden and Loke are the sources of numerous nearbottom seawater temperature and $E h$ anomalies detected by the CAMPER vehicle, indicating widespread diffuse hydrothermal discharge. Two plume horizons were also detected over the axial valley during the 2001 AMORE cruises, one at $\sim 2500 \mathrm{~m}$ and one at $\sim 3300 \mathrm{~m}\left(\Delta \theta>0.7^{\circ} \mathrm{C}\right)$, and were the most extensive and voluminous of any on the Gakkel Ridge [Edmonds et al., 2003; Baker et al., 2004]. Water column plume experiments during the AGAVE cruise also identified hydrothermal plumes confined within the axial valley walls at $3000-3800 \mathrm{~m}$ that were generated by vents on the valley floor. Given their low-temperature $\left(\mathrm{T}<10^{\circ} \mathrm{C}\right)$, these hydrothermal fluids did not disperse great distances despite the weakly stratified water column and were traced to six spatially distinct sites, including plumes above Oden and Loke [Stranne et al., 2010]. Near-seafloor temperature and $E h$ anomalies identified distinct locations of diffuse, low-temperature hydrothermal fluids over 100's of meters on Oden and the apron of Loke. The volcanoes also host extensive microbial mats that are supported by hydrothermal fluid flow [Helmke et al., 2007]. The microbial mats observed at the $85^{\circ} \mathrm{E}$ site are similar in appearance (i.e., orange, gelatinous texture) to those produced by $\mathrm{Fe}$-oxidizing bacteria found at Loihi Seamount, Hawaii [e.g., Emerson and Moyer, 2002; Edwards et al., 2011]. The presence of diffuse hydrothermal discharge along both axis-parallel volcanic lineations suggests that regional tectonics make the seafloor permeable to hydrothermal 
circulation to a hot rock body underlying the valley floor and are key in controlling fluid discharge sites. However, the greater abundance of hydrothermal anomalies on the southern lineament suggests that the vigor of discharge is related to the relative age of volcanic activity.

\subsection{Volcanic Processes at $85^{\circ} \mathrm{E}$}

[40] Our evaluation of seafloor imagery from the 2007 AGAVE cruise, which is located within the area of high intensity backscatter identified by Edwards et al. [2001] (Figure 3), indicates that the region has experienced multiple, small-volume eruptions from discrete source vents over time. Our results agree with Edwards et al. [2001] interpretation of the area of high intensity backscatter as a region formed by multiple eruptions, which they based on observations of faults crosscutting the area. The sedimentation rate in the Gakkel Ridge is estimated to be $1-3 \mathrm{~cm} \mathrm{kyr}^{-1}$ [Backman et al., 2004] and penetration into pelagic sediment by the $12 \mathrm{kHz}$ SCICEX side scan sonar could easily exceed $1 \mathrm{~m}$ without dramatic signal attenuation [Mitchell, 1993], thus the region of high backscatter at $85^{\circ} \mathrm{E}$ could be produced by eruptions $>1$ million years in age. All glasses sampled on Oden and Loke [cf. Shaw et al., 2010] and volcaniclastic samples (Figure 1a) are age-constrained by U-series disequilibria (i.e., ${ }^{226} \mathrm{Ra} /{ }^{230} \mathrm{Th}=3.07$ to $3.65 \pm 3 \%$ ) to less than 8000 years, and one volcaniclastic sample (Sample 13-1) is age-constrained (i.e., ${ }^{210} \mathrm{~Pb} / 226 \mathrm{Ra}=0.89 \pm 9 \%$ ) to less than 100 years old [Elkins, 2009]. Thus, we conclude that the large region of high intensity backscatter from SCICEX 1999 represents a zone of seafloor (up to $1 \mathrm{Myr}$ in age) with thin pelagic sediment coverage and only a small area of fresh lavas on the southern lineament may be as recent as the 1999 seismic swarms. Our new observations of small-volume eruptions at the Gakkel Ridge challenge the hypothesis that eruption volume varies inversely with spreading rate across the global MOR system [Perfit and Chadwick, 1998; Sinton et al., 2002].

\subsection{Evidence of Deep Explosive Eruptions}

[41] Unconsolidated volcaniclastic depositsdominated by fine-grained, glassy clasts but also containing bubble-wall fragments-blanket the axial valley with variable thicknesses up to $10 \mathrm{~cm}$ over an area $\sim 5 \mathrm{~km} \times 10 \mathrm{~km}$. Although many formation mechanisms are postulated for submarine basaltic volcaniclasts (e.g., fuel-coolant interaction, quench granulation, hydromagmatic processes) the widespread distribution of deposits within the axial valley at depths greater than $3.6 \mathrm{~km}$ (e.g., at pressures greater than the critical point of seawater) point to formation by pyroclastic explosion [Büttner et al., 2002; Zimanowski and Büttner, 2003]. In particular, the abundance of the fresh volcaniclastic deposits on lava surfaces of varying ages argues against quench granulation from intact lava flows as a primary mechanism of formation. In addition, the presence of fresh volcaniclasts in the shallowest portions of the study area, where they are locally piled on top of pillows and on top of ridgelines, suggests that the volcaniclasts are deposited by falling through the water column rather than flow along the seafloor. This suggests that volcaniclasts are lofted into the water column at the eruptive vent. Similar clasts were recovered in box cores at the $60^{\circ} \mathrm{E}$ volcanic center on the Gakkel Ridge and may indicate similar explosive eruptions along the EVZ, though in that case clasts were interpreted as spallation from lava flow surfaces [Mühe et al., 1997].

[42] Volcaniclastic deposit thicknesses correlate with relative apparent ages of lava surfaces, with the thinnest deposits on near-zero-age lavas on Oden and Loke Volcanoes. On more oxidized, relatively older flows of Oden and Loke we observe thicker coverage. Abrupt changes in volcaniclastic deposit thickness at eruptive unit boundaries indicate thickness variations related to multiple episodes of explosive eruption rather than distance from a source, which would result in more gradual deposit variation. Deposits are thickest on the axial ridges, especially Duque's Hill, which we interpret to be the oldest surfaces in the study area. Overall, there is no clear gradient in volcaniclastic deposit thickness as would be expected with increasing proximity to an explosive source. If a single explosive source were to be invoked, it would have to be within or north of the two AVRs. However, the volcaniclastic deposits all appear to be much fresher than the lava flows on the AVRs, and the source of the youngest eruptions in the study are south of the AVRs on the southern lineament. From settling velocity experiments and modeling, Barreyre et al. [2011] found that a buoyant plume of hydrothermal fluid during an eruption (i.e., hydrothermal megaplume) could disperse clasts $\sim 400 \mathrm{~m}$ at most from a source vent on the Gakkel Ridge (assuming nominal current speeds of $\sim 1 \mathrm{~cm} / \mathrm{s}$ [Stranne et al., 2010]). Thus, multiple source vents distributed within the axial valley are required to disperse clasts along $\sim 10 \mathrm{~km}$ of seafloor and to create abrupt boundaries in deposit thickness. We further note that the cratered morphology and presence of unweathered talus on the summit and flanks of Oden Volcano are consistent with a Vulcanian 
explosion mechanism, where the catastrophic expansion of magmatic volatiles occurs in the shallow subsurface, thereby generating a central, talus-filled crater and ejecting talus blocks onto the summit rim and flanks of the cone.

\subsection{A Model of Effusive and Explosive Eruption at $85^{\circ} \mathrm{E}$}

[43] The depth of the axial valley of our study area at 3600-4200 mbsl is deeper than the maximum depth at which steam explosion can occur. The physical characteristics and widespread dispersal of the pyroclastic deposits lead us to suspect a highly energetic eruption driven by magmatic volatiles. Given the typical MORB geochemistry [Shaw et al., 2010] and low vesicularity of the samples, we presume that the $\mathrm{CO}_{2}$ driving the eruption must have accumulated at depth, largely decoupled from the erupting lava [Head and Wilson, 2003]. Thus magmatic volatiles, particularly $\mathrm{CO}_{2}$ because it has the smallest solubility of the major gases, represent the most likely driving force for explosivity [Bottinga and Javoy, 1990; Head and Wilson, 2003; White et al., 2003].

[44] $\mathrm{CO}_{2}$ exsolution can begin somewhere between $45-20 \mathrm{~km}$ below sea level in upward moving MORB depending on the initial concentration in the melt [Bottinga and Javoy, 1990]. Although Shaw et al. [2010] suggest that initial concentrations may not have been much higher than the maximum $\mathrm{CO}_{2}$ that they measured (1596 ppm), even small supersaturations at depths $>10 \mathrm{~km}$ would allow for some free gas to exsolve. We propose that over time a significant volume of exsolved volatiles may accumulate in crustal magma chambers. We assess the feasibility of such a model by examining the timescales of melting and magnitude of melt accumulation necessary to generate the required amounts of $\mathrm{CO}_{2}$ (see Appendix A). By modeling the amount of magma produced due to passive mantle upwelling [e.g., Forsyth, 1993] and calculating the supersaturation in $\mathrm{CO}_{2}$ at a given storage depth within the crust, we estimate that realistic timescales for gas accumulation would be on the order of 1500-2000 years. As the expected repose interval for eruptions at ultraslow spreading ridges is 10,000 to 100,000 years [e.g., Perfit and Chadwick, 1998], this timescale for melt accumulation suggests storage of $\mathrm{CO}_{2}$ in crustal reservoirs is a viable mechanism.

[45] Gas bubbles can form a foam layer in a reservoir with a gas volume fraction that can be stable over 90\% [Vergniolle and Jaupart, 1990]. The sequestered volatiles may then be released during an eruptive episode, leading to explosive discharge spreading pyroclastic material over seafloor areas proximal to the source vent [Head and Wilson, 2003; Sohn et al., 2008]. We propose that gasdepleted magma, rising more slowly in an eruption conduit, may also erupt during these explosive episodes. A slowly rising magma would erupt lowvesicularity, effusive flows in equilibrium with $\mathrm{CO}_{2}$ at seafloor depths, similar to those observed at the $85^{\circ} \mathrm{E}$ segment [e.g., Shaw et al., 2010]. This model is consistent with our observations of widespread pyroclastic deposits and avesicular, effusive lavas, and this type of eruption has been directly observed at W. Mata Volcano in the Lau Basin [Resing et al., 2011].

\section{Conclusions}

[46] Recent volcanic activity at the $85^{\circ} \mathrm{E}$ segment of the ultraslow spreading Gakkel Ridge consists of small volume effusive and explosive eruptions sourced from multiple volcanic features within the axial valley. These eruptions have produced AVRs and volcanic cones, with many of the latter exhibiting distinctive central craters. Similar volcanic cones and AVRs are observed in the axial valley at the very slow spreading Southwest Indian Ridge [Mendel and Sauter, 1997; Cannat et al., 1999; Sauter et al., 2001] as well as the slow spreading Mid-Atlantic Ridge [Smith and Cann, 1990]. All of the "fresh" lavas observed in our surveys were found on the southernmost volcanic lineament at the Oden, Thor, and Loke volcanic cones, which also coincides with the region where near-bottom $E h$ and thermal anomalies were observed in the water column, and where microbial mats were observed on the seafloor. These observations demonstrate that the 1999 seismic swarm may have been associated with a series of small volume eruptions featuring both explosive and effusive discharge.

[47] We model the widespread volcaniclastic deposits observed on the seafloor at the $85^{\circ} \mathrm{E}$ segment as having been generated by the explosive discharge of $\mathrm{CO}_{2}$ that accumulated in (possibly deep) crustal melt reservoirs over a period of time on the order of the eruption interval for an ultraslow-spreading ridge ( $\sim 10,000 \mathrm{yr})$. We envision that $\mathrm{CO}_{2}$ 'bubbles' escaped from crustal melt reservoirs during eruptive events, rising through a more slowly ascending magma column before explosively discharging at, or in some cases just beneath, the seafloor. The energy released during explosive discharge, combined with the buoyant rise of hot fluid, lofts fragmented clasts of 
rapidly cooling magma into the water column, and they subsequently settle onto the seafloor as fall deposits in the region surrounding the source vent. The volcaniclasts themselves are avesicular with dissolved $\mathrm{CO}_{2}$ in equilibrium with seafloor pressures because magmas (unlike the gas bubbles) rise slowly in the eruption conduit, and therefore continually exsolve excess $\mathrm{CO}_{2}$ along their vertical path to the seafloor from the crustal melt reservoir. Excess gas exsolved from magmas during a slow rise to the seafloor may be incorporated into gas 'bubbles' escaping from the melt reservoir, and thereby enhance explosive activity.

\section{Appendix A: Accumulation of $\mathrm{CO}_{2}$ in a Crustal Magma Chamber}

[48] The physical characteristics of the volcaniclastic deposits lead us to suspect a highly energetic eruption driven by magmatic volatiles. Given the typical MORB geochemistry and low vesicularity of the samples, we presume that the $\mathrm{CO}_{2}$ driving the eruption must have accumulated at depth, largely decoupled from the erupting lava. We assess the feasibility of such a model by examining the timescales of melting and magnitude of melt accumulation necessary to generate the required amounts of $\mathrm{CO}_{2}$. Although the volume of gas required to drive an explosive eruption in this environment is not known, a conservative estimate is that the gas volume is 3 times that of the magma volume emplaced at the seafloor [e.g., Sohn et al., 2008; Head and Wilson, 2003].

[49] A minimum time to accumulate the $\mathrm{CO}_{2}$ is determined by assuming that $\mathrm{CO}_{2}$ behaves perfectly incompatibly and that all $\mathrm{CO}_{2}$ extracted from the mantle is available to contribute to an explosive eruption. The latter assumption is likely unreasonable, but places a lower bound on the timescale of melt generation. If all mantle that passes through the melting zone is stripped of its carbon by newly formed magmas, we can estimate the $\mathrm{CO}_{2}$ accumulation by assuming a mantle carbon concentration and the length of ridge over which melts are focused. The volume flux of mantle $\left(Q_{m}\right)$ through the melting region is related to spreading rate by,

$$
Q_{m}=\left(L_{x} L_{y}\right)\left(2 U_{o} / \pi\right)
$$

in the case of a uniform viscosity mantle [Reid and Jackson, 1981]. The melting column width $\left(L_{x}\right)$ is derived from the height of the melting column, which we set to $40 \mathrm{~km}$ (Figure S10 in the auxiliary material). The along-axis length of ridge from which melts accumulate $\left(L_{y}\right)$ is set to $30 \mathrm{~km}$, consistent with the spacing of volcanic centers in the Eastern Volcanic Zone. The full spreading rate $\left(U_{o}\right)$ is $9 \mathrm{~mm} \mathrm{yr}^{-1}$. With a mantle density of $3500 \mathrm{~kg} \mathrm{~m}^{-3}$, a mantle $\mathrm{CO}_{2}$ concentration of 134 ppm [Shaw et al., 2010], and assuming ideal gas behavior, the time necessary to extract sufficient $\mathrm{CO}_{2}$ from the mantle is 1130 years for a $10^{6} \mathrm{~m}^{3}$ eruption (time scales linearly with eruption volume in this calculation).

[50] A more realistic estimate of the timescale of melt accumulation can be determined by modeling the amount of magma produced due to passive mantle upwelling and calculating the supersaturation in $\mathrm{CO}_{2}$ at a given storage depth within the crust. Here we rely on the formulation from Forsyth [1993], where melt production per unit length of ridge per unit time $(\dot{M})$ is related to spreading rate by:

$$
\dot{M}=\frac{B Z_{o}^{2} U_{o}}{2}
$$

where $B$ is the mantle melt productivity (fraction of melt per km of uplift above the solidus) and $Z_{o}$ is the thickness of the melting column (depth of solidus measured from the base of the crust). The amount of melt produced over the region (Figure S10 in the auxiliary material) as a function of time is combined with the $\mathrm{CO}_{2}$ contributed from the mantle over the same time interval and then the magma is stored at a depth of $7.5 \mathrm{~km}$ depth in the crust, consistent with data from melt inclusions from this area [Shaw et al., 2010]. At that depth $\mathrm{CO}_{2}$ solubility is $\sim 1200 \mathrm{ppm}$ $(0.0012 \mathrm{wt} \%)$ given observed water concentrations of $0.25 \mathrm{wt} \%$ [Shaw et al., 2010]. The annual melt production we calculate of $1.87 \times 10^{9} \mathrm{~kg} \mathrm{yr}^{-1}$ and the annual $\mathrm{CO}_{2}$ contribution from the mantle of $6.18 \times 10^{6} \mathrm{~kg} \mathrm{yr}^{-1}$ results in $\mathrm{CO}_{2}$ concentrations in the melt of $\sim 3300 \mathrm{ppm}$. Thus, nearly two-thirds of the $\mathrm{CO}_{2}$ extracted from the mantle could be stored as a free gas in a reasonably placed crustal magma chamber. As such, more realistic timescales for gas accumulation would be on the order of 1500-2000 years. As the expected repose interval for eruptions at ultraslow-spreading ridges is 10,000 to 100,000 years [e.g., Perfit and Chadwick, 1998], this timescale for melt accumulation suggests storage of $\mathrm{CO}_{2}$ in crustal reservoirs is a viable mechanism.

\section{Acknowledgments}

[51] Many thanks to A. Shaw, J. Bailey, J. Kemp, W. Lange and the Advanced Imaging Laboratory at WHOI, WHOI Graphics, 
and the crew of icebreaker I/B Oden. We gratefully acknowledge the financial support of the National Aeronautics and Space Administration, the National Science Foundation (N.S.F.), the International Polar Year 2007-2008, and Woods Hole Oceanographic Institution; and the graduate support provided by N.S.F., the NDSEG Fellowship, and WHOI Deep Ocean Exploration Institute.

\section{References}

Backman, J., M. Jakobsson, R. Løvlie, L. Polyak, and L. A. Febo (2004), Is the central Arctic Ocean a sediment starved basin?, Quat. Sci. Rev., 23, 1435-1454, doi:10.1016/ j.quascirev.2003.12.005.

Baker, E. T., R. A. Feely, M. J. Mottl, F. T. Sansone, C. G. Wheat, J. A. Resing, and J. E. Lupton (1994), Hydrothermal plumes along the East Pacific Rise, $8^{\circ} 40^{\prime}$ to $11^{\circ} 50^{\prime} \mathrm{N}$ : Plume distribution and relationship to the apparent magmatic budget, Earth Planet. Sci. Lett., 128, 1-17, doi:10.1016/0012821X(94)90022-1.

Baker, E. T., H. N. Edmonds, P. J. Michael, W. Bach, H. J. B. Dick, J. E. Snow, S. L. Walker, N. R. Banerjee, and C. H. Langmuir (2004), Hydrothermal venting in magma deserts: The ultraslow-spreading Gakkel and Southwest Indian Ridges, Geochem. Geophys. Geosyst., 5, Q08002, doi:10.1029/ 2004GC000712.

Ballard, R. D., and T. H. van Andel (1977), Morphology and tectonics of the inner rift valley at lat $36^{\circ} 50^{\prime} \mathrm{N}$ on the MidAtlantic Ridge, Geol. Soc. Am. Bull., 88, 507-530, doi:10.1130/0016-7606(1977)88<507:MATOTI >2.0.CO;2.

Ballard, R. D., W. B. Bryan, J. R. Heirtzler, G. Keller, J. G. Moore, and T. van Andel (1975), Manned submersible operations in the FAMOUS area, Mid-Atlantic Ridge, Science, 190, 103-108.

Ballard, R. D., R. T. Holcomb, and T. H. van Andel (1979), The Galapagos rift at $86^{\circ} \mathrm{W}: 3$. Sheet flows, collapse pits and lava lakes of the rift valley, J. Geophys. Res., 84, 5407-5422, doi:10.1029/JB084iB10p05407.

Barreyre, T., S. A. Soule, and R. A. Sohn (2011), Dispersal of volcaniclasts during deep-sea eruptions: Settling velocities and entrainment in buoyant seawater plumes, J. Volcanol. Geotherm. Res., 205, 84-93, doi:10.1016/j.jvolgeores.2011.05.006.

Batiza, R., D. J. Fornari, D. A. Vanko, and P. Lonsdale (1984), Craters, calderas, and hyaloclastites on young Pacific seamounts, J. Geophys. Res., 89(B10), 8371-8390, doi:10.1029/ JB089iB10p08371.

Behn, M. D., and G. Ito (2008), Magmatic and tectonic extension at mid-ocean ridges: 1 . Controls on fault characteristics, Geochem. Geophys. Geosyst., 9, Q08O10, doi:10.1029/ 2008GC001965.

Bonatti, E., and C. G. A. Harrison (1988), Eruption styles of basalt in oceanic spreading ridges and seamounts: Effect of magma temperature and viscosity, J. Geophys. Res., 93(B4), 2967-2980, doi:10.1029/JB093iB04p02967.

Bottinga, Y., and M. Javoy (1990), MORB degassing: Bubble growth and ascent, Chem. Geol., 81, 255-270, doi:10.1016/ 0009-2541(90)90050-H.

Bown, J. W., and R. S. White (1994), Variation with spreading rate of oceanic crustal thickness and geochemistry, Earth Planet. Sci. Lett., 121, 435-449, doi:10.1016/0012-821X(94) 90082-5.

Bryden, H. L. (1973), New polynomials for thermal expansion, adiabatic temperature gradient and potential temperature of sea water, Deep Sea Res., 20, 401-408.
Büttner, R., P. Dellino, L. La Volpe, V. Lorenz, and B. Zimanowski (2002), Thermohydraulic explosions in phreatomagmatic eruptions as evidenced by the comparison between pyroclasts and products from Molten Fuel Coolant Interaction experiments, J. Geophys. Res., 107(B11), 2277, doi:10.1029/2001JB000511.

Cann, J. R., and D. K. Smith (2005), Evolution of volcanism and faulting in a segment of the Mid-Atlantic Ridge at $25^{\circ} \mathrm{N}$ Geochem. Geophys. Geosyst., 6, Q09008, doi:10.1029/ $2005 \mathrm{GC} 000954$.

Cannat, M. (1996), How thick is the magmatic crust at slow spreading oceanic ridges?, J. Geophys. Res., 101(B2), 2847-2857, doi:10.1029/95JB03116.

Cannat, M., C. Rommevaux-Jestin, D. Sauter, C. Deplus, and V. Mendel (1999), Formation of the axial relief at the very slow spreading Southwest Indian Ridge $\left(49^{\circ}\right.$ to $\left.69^{\circ} \mathrm{E}\right)$, J. Geophys. Res., 104(B10), 22,825-22,843, doi:10.1029/ 1999JB900195.

Chadwick, W. W., Jr., D. S. Scheirer, R. W. Embley, and H. P. Johnson (2001), High-resolution bathymetric surveys using scanning sonars: Lava flow morphology, hydrothermal vents, and geologic structure at recent eruption sites on the Juan de Fuca Ridge, J. Geophys. Res., 106(B8), 16,075-16,099, doi:10.1029/2001JB000297.

Chadwick, W. W., K. V. Cashman, R. W. Embley, H. Matsumoto, R. P. Dziak, C. E. J. de Ronde, T. K. Lau, N. D. Deardorff, and S. G. Merle (2008), Direct video and hydrophone observations of submarine eruptions at NW Rota-1 volcano, Mariana arc, J. Geophys. Res., 113, B08S10, doi:10.1029/ 2007JB005215.

Clague, D. A., A. S. Davis, J. L. Bischoff, J. E. Dixon, and R. Geyer (2000), Bubble-wall fragments formed by submarine steam explosions on Loihi Seamount and Kilauea Volcano, Bull. Volcanol., 61, 437-449, doi:10.1007/ PL00008910.

Clague, D. A., R. Batiza, J. Head, and A. S. Davis (2003), Pyroclastic and hydroclastic deposits on Loihi Seamount, Hawaii, in Explosive Subaqueous Volcanism, Geophys. Monogr. Ser., vol. 140, edited by J. D. L. White, J. L. Smellie, and D. A. Clague, pp. 73-95, AGU, Washington, D. C., doi:10.1029/ 140GM05.

Clague, D. A., J. B. Paduan, and A. S. Davis (2009), Widespread strombolian eruptions of mid-ocean ridge basalt, J. Volcanol. Geotherm. Res., 180, 171-188, doi:10.1016/ j.jvolgeores.2008.08.007.

Coakley, B. J., and J. R. Cochran (1998), Gravity evidence of very thin crust at the Gakkel Ridge (Arctic Ocean), Earth Planet. Sci. Lett., 162, 81-95, doi:10.1016/S0012821X(98)00158-7.

Cochran, J. R. (2008), Seamount volcanism along the Gakkel Ridge, Arctic Ocean, Geophys. J. Int., 174, 1153-1173, doi:10.1111/j.1365-246X.2008.03860.x.

Deardorff, N. D., K. V. Cashman, and W. W. Chadwick (2011), Observations of eruptive plume dynamics and pyroclastic deposits from submarine explosive eruptions at NW Rota-1, Mariana arc, J. Volcanol. Geotherm. Res., 202, 47-59, doi:10.1016/j.jvolgeores.2011.01.003.

DeMets, C., R. G. Gordon, D. F. Argus, and S. Stein (1994), Current plate motions, Geophys. Res. Lett., 21, 2191-2194, doi:10.1029/94GL02118.

Dick, H. J. B., J. Lin, and H. Schouten (2003), An ultraslow spreading class of ocean ridge, Nature, 426, 405-412, doi:10.1038/nature02128.

Driesner, T., and S. Geiger (2007), Numerical simulation of multiphase fluid flow in hydrothermal systems, in Fluid-Fluid 
Interactions, Rev. in Mineral. and Geochem., vol. 65, edited by A. Liebscher and C. A. Heinrich, pp. 187-212, Mineral. Soc. of Am., Washington, D. C., doi:10.2138/rmg.2007.65.6. Edmonds, H. N., P. J. Michael, E. T. Baker, D. P. Connelly, J. E. Snow, C. H. Langmuir, J. H. B. Dick, R. Muhe, C. R. German, and D. W. Graham (2003), Discovery of abundant hydrothermal venting on the ultraslow spreading Gakkel ridge in the Arctic Ocean, Nature, 421, 252-256, doi:10.1038/ nature 01351 .

Edwards, K. J., et al. (2011), Ultra-diffuse hydrothermal venting supports Fe-oxidizing bacteria and massive umber deposition at $5000 \mathrm{~m}$ off Hawaii, ISME J., 5, 1748-1758, doi:10.1038/ismej.2011.48.

Edwards, M. H., and B. J. Coakley (2003), SCICEX investigations of the Arctic Ocean System, Chem. Erde, 63, 281-328, doi:10.1078/0009-2819-00039.

Edwards, M. H., G. J. Kurras, M. Tolstoy, D. R. Bohnenstiehl, B. J. Coakley, and J. R. Cochran (2001), Evidence of recent volcanic activity on the ultraslow spreading Gakkel ridge, Nature, 409, 808-812, doi:10.1038/35057258.

Eissen, J. P., Y. Fouquet, D. Hardy, and H. Ondreas (2003), Recent MORB volcaniclastic explosive deposits from between 500 and 1750 m.b.s.l. on the axis of the Mid-Atlantic Ridge, south of the Azores, in Explosive Subaqueous Volcanism, Geophys. Monogr. Ser., vol. 140, edited by J. D. L. White, J. L. Smellie, and D. A. Clague, pp. 143-166, AGU, Washington, D. C., doi:10.1029/140GM09.

Elkins, L. J. (2009), Basalt petrogenesis beneath slow- and ultraslow-spreading Arctic mid-ocean ridges, $\mathrm{PhD}$ thesis, MITWHOI Jt. Program in Oceanogr., Mass. Inst. of Technol., Cambridge.

Emerson, D., and C. L. Moyer (2002), Neutrophilic Fe-oxidizing bacteria are abundant at the Loihi Seamount hydrothermal vents and play a major role in Fe oxide deposition, Appl. Environ. Microbiol., 68(6), 3085-3093, doi:10.1128/AEM. 68.6.3085-3093.2002.

Fink, J. H., and R. W. Griffiths (1992), A laboratory analog study of the surface morphology of lava flows extruded from point and line sources, J. Volcanol. Geotherm. Res., 54, 19-32, doi:10.1016/0377-0273(92)90112-Q.

Fofonoff, N. P., and R. C. Millard Jr. (1983), Algorithms for computation of fundamental properties of seawater, UNESCO Tech. Pap. Mar. Sci., 44, U.N. Educ., Sci. and Cult. Organ., Paris.

Fornari, D. et al. (2004), Submarine lava flow emplacement at the East Pacific Rise $9^{\circ} 50^{\prime} \mathrm{N}$ : Implications for uppermost ocean crust stratigraphy and hydrothermal fluid circulation, in The Thermal Structure of the Ocean Crust and the Dynamics of Hydrothermal Circulation, Geophys. Monogr. Ser., vol. 148, edited by C. R. German, J. Lin, and L. M. Parson, pp. 187-218, AGU, Washington, D. C.

Forsyth, D. W. (1993), Crustal thickness and the average depth and degree of melting in fractional melting models of passive flow beneath mid-ocean ridges, J. Geophys. Res., 98(B9), 16,073-16,079, doi:10.1029/93JB01722.

Fundis, A. T., S. A. Soule, D. J. Fornari, and M. R. Perfit (2010), Paving the seafloor: Volcanic emplacement processes during the 2005-2006 eruptions at the fast spreading East Pacific Rise, $9^{\circ} 50^{\prime} \mathrm{N}$, Geochem. Geophys. Geosyst., 11, Q08024, doi:10.1029/2010GC003058.

Garry, W. B., T. K. P. Gregg, S. A. Soule, and D. J. Fornari (2006), Formation of submarine lava channel textures: Insights from laboratory simulations, J. Geophys. Res., 111, B03104, doi:10.1029/2005JB003796.
Gregg, T. K. P., and J. H. Fink (1995), Quantification of submarine lava-flow morphology through analog experiments, Geology, 23(1), 73-76, doi:10.1130/0091-7613(1995) $023<0073$ :QOSLFM>2.3.CO;2.

Head, J. W. I., and L. Wilson (2003), Deep submarine volcaniclastic eruptions: Theory and predicted landforms and deposits, J. Volcanol. Geotherm. Res., 121, 155-193, doi:10.1016/ S0377-0273(02)00425-0.

Helmke, E., et al. (2007), Microbial communities at nonvolcanic and volcanic sites of the Gakkel ridge, Eos Trans. $A G U, 88(52)$, Fall Meet. Suppl., Abstract OS42A-01.

Helo, C., M.-A. Longpre, N. Shimizu, D. A. Clague, and J. Stix (2011), Explosive eruptions at mid-ocean ridges driven by $\mathrm{CO}_{2}$-rich magmas, Nat. Geosci., 4, 260-263, doi:10.1038/ ngeo1104.

Jakobsson, M., R. Macnab, L. Mayer, R. Anderson, M. Edwards, J. Hatzky, H.-W. Schenke, and P. Johnson (2008), An improved bathymetric portrayal of the Arctic Ocean: Implications for ocean modeling and geological, geophysical and oceanographic analyses, Geophys. Res. Lett., 35, L07602, doi:10.1029/2008GL033520.

Jokat, W., and M. C. Schmidt-Aursch (2007), Geophysical characteristics of the ultraslow spreading Gakkel Ridge, Arctic Ocean, Geophys. J. Int., 168, 983-998, doi:10.1111/ j.1365-246X.2006.03278.x.

Jokat, W., O. Ritzmann, M. C. Schmidt-Aursch, S. Drachev, S. Gauger, and J. Snow (2003), Geophysical evidence for reduced melt production on the Arctic ultraslow Gakkel midocean ridge, Nature, 423, 962-965, doi:10.1038/nature01706.

Korger, E. I. M., and V. Schlindwein (2012), Performance of localization algorithms for teleseismic mid-ocean ridge earthquakes: The 1999 Gakkel Ridge earthquake swarm and its geological interpretation, Geophys. J. Int., 188, 613-625, doi:10.1111/j.1365-246X.2011.05282.x.

Le Douaran, S., and J. Francheteau (1981), Axial depth anomalies from 10 to $50^{\circ}$ north along the Mid-Atlantic Ridge: Correlation with other mantle properties, Earth Planet. Sci. Lett., 54, 29-47, doi:10.1016/0012-821X(81)90066-2.

Lonsdale, P. (1977a), Abyssal pahoehoe with lava coils at the Galapagos rift, Geology, 5, 147-152, doi:10.1130/00917613(1977)5<147:APWLCA $>2.0 . C O ; 2$.

Lonsdale, P. (1977b), Structural geomorphology of a fastspreading rise crest: The East Pacific Rise near $3^{\circ} 25^{\prime} \mathrm{S}$, Mar. Geophys. Res., 3, 251-293, doi:10.1007/BF00285656.

Macdonald, K. C. (1982), Mid-Ocean Ridges: Fine scale tectonic, volcanic and hydrothermal processes within the plate boundary zone, Annu. Rev. Earth Planet. Sci., 10, 155-190, doi:10.1146/annurev.ea.10.050182.001103.

Maicher, D., and J. D. L. White (2001), The formation of deepsea Limu o Pele, Bull. Volcanol., 63, 482-496, doi:10.1007/ s004450100165.

Maicher, D., J. D. L. White, and R. Batiza (2000), Sheet hyaloclastite: Density-current deposits of quench no bubbleburst fragments from thin, glassy sheet lava flows, Seamount Six, eastern Pacific Ocean, Mar. Geol., 171, 75-94, doi:10.1016/S0025-3227(00)00109-2.

Mattox, T. N., and M. T. Mangan (1997), Littoral hydrovolcanic explosions: A case study of lava-seawater interaction at Kilauea Volcano, J. Volcanol. Geotherm. Res., 75, 1-17, doi:10.1016/S0377-0273(96)00048-0.

Mendel, V., and D. Sauter (1997), Seamount volcanism at the super slow-spreading Southwest Indian Ridge between $57^{\circ} \mathrm{E}$ and $70^{\circ} \mathrm{E}$, Geology, 25(2), 99-102.

Michael, P. J., et al. (2003), Magmatism and amagmatic seafloor generation at the ultraslow spreading Gakkel ridge, 
Arctic Ocean, Nature, 423, 956-961, doi:10.1038/ nature 01704

Mitchell, N. C. (1993), A model for attenuation of backscatter due to sediment accumulations and its application to determine sediment thickness with GLORIA sidescan sonar, J. Geophys. Res., 98(B12), 22,477-22,493, doi:10.1029/ 93JB02217.

Mühe, R., H. Bohrmann, D. Garbe-Schönberg, and H. Kassens (1997), E-MORB glasses from the Gakkel Ridge (Arctic Ocean) at $87^{\circ} \mathrm{N}$ : Evidence for the Earth's most northerly volcanic activity, Earth Planet. Sci. Lett., 152, 1-9, doi:10.1016/ S0012-821X(97)00152-0.

Müller, C., and W. Jokat (2000), Seismic evidence for volcanic activity discovered in central Arctic, Eos Trans. AGU, 81, 265-269, doi:10.1029/00EO00186.

Nakamura, K., S. Veirs, C. P. Sarason, R. E. McDuff, F. Stahr, D. R. Yoerger, and A. M. Bradley (2000), Electrochemical signals in rising buoyant plumes and tidally oscillating plumes at the Main Endeavour vent field, Juan de Fuca Ridge, Eos Trans, $A G U, 81(48)$, Fall Meet. Suppl., Abstract OS52I-05.

Namiki, A., and M. Manga (2008), Transition between fragmentation and permeable outgassing of low viscocity magmas, J. Volcanol. Geotherm. Res., 169, 48-60, doi:10.1016/ j.jvolgeores.2007.07.020.

Neumann, G. A., and D. W. Forsyth (1993), Comparison of marine gravity from shipboard and high-density satellite altimetry along the Mid-Atlantic Ridge, $30.5^{\circ}-35.5^{\circ} \mathrm{S}$, Geophys. Res. Lett., 20(15), 1639-1642, doi:10.1029/93GL01487.

Perfit, M. R., and W. W. Chadwick Jr. (1998), Magmatism at mid-ocean ridges: Constraints from volcanological and geochemical investigations, in Faulting and Magmatism at Mid-Ocean Ridges, Geophys. Monogr. Ser., vol. 106, edited by W. R. Buck et al., pp. 59-115, AGU, Washington, D. C., doi:10.1029/GM106p0059.

Polacci, M., D. R. Baker, L. Bai, and L. Mancini (2008), Large vesicles record pathways of degassing at basaltic volcanoes, Bull. Volcanol., 70, 1023-1029, doi:10.1007/s00445-0070184-8.

Ramberg, I. B., and T. H. van Andel (1977), Morphology and tectonic evolution of the rift valley at lat $36^{\circ} 30^{\prime} \mathrm{N}$, MidAtlantic Ridge, Geol. Soc. Am. Bull., 88, 577-586, doi:10.1130/0016-7606(1977)88<577:MATEOT>2.0.CO;2.

Reid, I., and H. R. Jackson (1981), Oceanic spreading rate and crustal thickness, Mar. Geophys. Res., 5, 165-172.

Resing, J. A., et al. (2011), Active submarine eruption of boninite in the northeastern Lau Basin, Nat. Geosci., 4(11), 799-806, doi:10.1038/ngeo1275.

Rubin, K. H., and J. M. Sinton (2007), Inferences on midocean ridge thermal and magmatic structure from MORB compositions, Earth Planet. Sci. Lett., 260, 257-276, doi:10.1016/j.epsl.2007.05.035.

Ryan, W. B. F., et al. (2009), Global Multi-Resolution Topography (GMRT) synthesis data set, Geochem. Geophys. Geosyst., 10, Q03014, doi:10.1029/2008GC002332.

Sauter, D., P. Patriat, C. Rommevaux-Jestin, M. Cannat, and A. Briais (2001), The Southwest Indian Ridge between $49^{\circ} 15^{\prime} \mathrm{E}$ and $57^{\circ} \mathrm{E}$ : Focused accretion and magma redistribution, Earth Planet. Sci. Lett., 192, 303-317, doi:10.1016/ S0012-821X(01)00455-1.

Schipper, C. I., and J. D. L. White (2010), No depth limit to hydrovolcanic limu o Pele: Analysis of limu from Lo'ihi Seamount, Hawai'i, Bull. Volcanol., 72, 149-164, doi:10.1007/ s00445-009-0315-5.
Schlindwein, V., and C. Riedel (2010), Location and source mechanism of sound signals at Gakkel ridge, Arctic Ocean: Submarine Strombolian activity in the 1999-2001 volcanic episode, Geochem. Geophys. Geosyst., 11, Q01002, doi:10.1029/ 2009GC002706.

Schlindwein, V., C. Müller, and W. Jokat (2007), Microseismicity of the ultraslow-spreading Gakkel Ridge, Arctic Ocean: A pilot study, Geophys. J. Int., 169, 100-112, doi:10.1111/ j.1365-246X.2006.03308.x.

Searle, R. C., et al. (2010), Structure and development of an axial volcanic ridge: Mid-Atlantic Ridge, $45^{\circ} \mathrm{N}$, Earth Planet. Sci. Lett., 299, 228-241, doi:10.1016/j.epsl.2010.09.003.

Sella, G. F., T. H. Dixon, and A. Mao (2002), REVEL: A model for recent plate velocities from space geodesy, J. Geophys. Res., 107(B4), 2081, doi:10.1029/2000JB000033.

Sempéré, J.-C., G. M. Purdy, and H. Schouten (1990), Segmentation of the Mid-Atlantic Ridge between $24^{\circ} \mathrm{N}$ and $30^{\circ} 40^{\prime} \mathrm{N}$, Nature, 344, 427-431, doi:10.1038/344427a0.

Sempéré, J.-C., J. Lin, H. S. Brown, H. Schouten, and G. M. Purdy (1993), Segmentation and morphotectonic variations along a slow-spreading center: The Mid-Atlantic Ridge $\left(24^{\circ} 00^{\prime} \mathrm{N}-30^{\circ} 40^{\prime} \mathrm{N}\right)$, Mar. Geophys. Res., 15, 153-200, doi:10.1007/BF01204232.

Shank, T. M., D. J. Fornari, K. L. Von Damm, M. D. Lilley, R. M. Haymon, and R. A. Lutz (1998), Temporal and spatial patterns of biological community development at nascent deep-sea hydrothermal vents $\left(9^{\circ} 50^{\prime} \mathrm{N}\right.$, East Pacific Rise), Deep Sea Res., Part II, 45, 465-515, doi:10.1016/S0967-0645(97) 00089-1.

Shaw, A. M., M. D. Behn, S. E. Humphris, R. A. Sohn, and P. M. Gregg (2010), Deep pooling of low degree melts and volatile fluxes at the $85^{\circ} \mathrm{E}$ segment of the Gakkel Ridge: Evidence from olivine-hosted melt inclusions and glasses, Earth Planet. Sci. Lett., 289, 311-322, doi:10.1016/j.eps1.2009.11.018.

Sinton, J. M., and R. S. Detrich (1992), Mid-ocean ridge magma chambers, J. Geophys. Res., 97(B1), 197-216, doi:10.1029/ 91JB02508.

Sinton, J., E. Bergmanis, K. Rubin, R. Batiza, T. K. P. Gregg, K. Grönvold, K. C. Macdonald, and S. M. White (2002), Volcanic eruptions on mid-ocean ridges: New evidence from the superfast spreading East Pacific Rise, $17^{\circ}-19^{\circ} \mathrm{S}, \mathrm{J}$. Geophys. Res., 107(B6), 2115, doi:10.1029/2000JB000090.

Small, C. (1994), A global analysis of mid-ocean ridge axial topography, Geophys. J. Int., 116, 64-84, doi:10.1111/ j.1365-246X.1994.tb02128.x.

Smith, D. K., and J. R. Cann (1990), Hundreds of small volcanoes on the median valley floor of the Mid-Atlantic Ridge at 24-30 ${ }^{\circ}$, Nature, 348, 152-155, doi:10.1038/348152a0.

Smith, D. K., and J. R. Cann (1992), The role of seamount volcanism in crustal construction at the Mid-Atlantic Ridge $\left(24^{\circ}-30^{\circ} \mathrm{N}\right)$, J. Geophys. Res., 97(B2), 1645-1658, doi:10.1029/91JB02507.

Smith, D. K., and J. R. Cann (1993), Building the crust at the Mid-Atlantic Ridge, Nature, 365, 707-715, doi:10.1038/ $365707 \mathrm{a} 0$.

Sohn, R. A., et al. (2008), Explosive volcanism on the ultraslow spreading Gakkel Ridge, Arctic Ocean, Nature, 453, 1236-1238, doi:10.1038/nature07075.

Soule, S. A., D. J. Fornari, M. R. Perfit, M. A. Tivey, W. I. Ridley, and H. Schouten (2005), Channelized lava flows at the East Pacific Rise crest $9^{\circ}-10^{\circ} \mathrm{N}$ : The importance of offaxis lava transport in developing the architecture of young oceanic crust, Geochem. Geophys. Geosyst., 6, Q08005, doi:10.1029/2005GC000912. 
Soule, S. A., D. J. Fornari, M. R. Perfit, and K. H. Rubin (2007), New insights into mid-ocean ridge volcanic processes from the 2005-2006 eruption of the East Pacific Rise, $9^{\circ} 46^{\prime} \mathrm{N}-9^{\circ} 56^{\prime} \mathrm{N}$, Geology, 35, 1079-1082, doi:10.1130/ G23924A.1.

Soule, S. A., J. Escartín, and D. J. Fornari (2009), A record of eruption and intrusion at a fast spreading ridge axis: Axial summit trough of the East Pacific Rise at $9-10^{\circ} \mathrm{N}$, Geochem. Geophys. Geosyst., 10, Q10T07, doi:10.1029/2008GC002354.

Standish, J. J., H. J. Dick, P. J. Michael, W. G. Melson, and T. O'Hearn (2008), MORB generation beneath the ultraslow spreading Southwest Indian Ridge $\left(9-25^{\circ} \mathrm{E}\right)$ : Major element chemistry and the importance of process versus source, Geochem. Geophys. Geosyst., 9, Q05004, doi:10.1029/ 2008 GC001959.

Staudigel, H., and D. A. Clague (2010), The geological history of deep-sea volcanoes: Biosphere, hydrosphere, and lithosphere interactions, Oceanography, 23(1), 58-71, doi:10.5670/ oceanog.2010.62.

Stranne, C., R. A. Sohn, B. Liljebladh, and K. Nakamura (2010), Analysis and modeling of hydrothermal plume data acquired from the $85^{\circ} \mathrm{E}$ segment of the Gakkel Ridge, J. Geophys. Res., 115, C06028, doi:10.1029/2009JC005776.

Stroncik, N. A., and H.-U. Schmincke (2002), Palagonite: A review, Int. J. Earth Sci., 91, 680-697, doi:10.1007/ s00531-001-0238-7.

Thiede, J., D. L. Clark, and Y. Herman (1990), Late Mesozoic and Cenozoic paleoceanography of the northern polar oceans, in The Arctic Ocean Region, vol. L, edited by A. Grantz, L. Johnson, and J. F. Sweeny, pp. 427-458, Geol. Soc. of Am., Boulder, Colo.
Tolstoy, M., D. R. Bohnenstiehl, M. H. Edwards, and G. J. Kurras (2001), Seismic character of volcanic activity at the ultraslow-spreading Gakkel Ridge, Geology, 29(12), 1139-1142, doi:10.1130/0091-7613(2001)029<1139:SCOVAA> 2.0.CO;2.

van Andel, T. H., and R. D. Ballard (1979), The Galapagos Rift at $86^{\circ} \mathrm{W}: 2$. Volcanism, structure, and evolution of the rift valley, J. Geophys. Res., 84(B10), 5390-5606, doi:10.1029/ JB084iB10p05390.

Vergniolle, S., and C. Jaupart (1990), Dynamics of degassing at Kilauea Volcano, Hawaii, J. Geophys. Res., 95(B3), 2793-2809, doi:10.1029/JB095iB03p02793.

Vogt, P. R., P. T. Taylor, L. C. Kovacs, and G. L. Johnson (1979), Detailed aeromagnetic investigations of the Arctic Basin, J. Geophys. Res., 84, 1071-1089, doi:10.1029/ JB084iB03p01071.

White, J. D. L., J. L. Smellie, and D. A. Clague (Eds.) (2003), Explosive Subaqueous Volcanism, Geophys. Monogr. Ser. vol. 140, AGU, Washington, D. C., doi:10.1029/GM140.

Wright, I. C. (1994), Nature and tectonic setting of the southern Kermadec submarine arc volcanoes: An overview, Mar. Geol., 118, 217-236, doi:10.1016/0025-3227(94)90085-X.

Zimanowski, B., and R. Büttner (2003), Phreatomagmatic explosions in subaqueous volcanism, in Explosive Subaqueous Volcanism, edited by J. D. L. White, J. L. Smellie, and D. A. Clague, Geophys. Monogr. Ser., vol. 140, pp. 51-60, AGU, Washington, D. C., doi:10.1029/140GM03. 